$2 / 3 \gamma / 10<\%$

\title{
Dr.2284
}

\section{Satellite Power System (SPS) Public Outreach Experiment}

December 1980
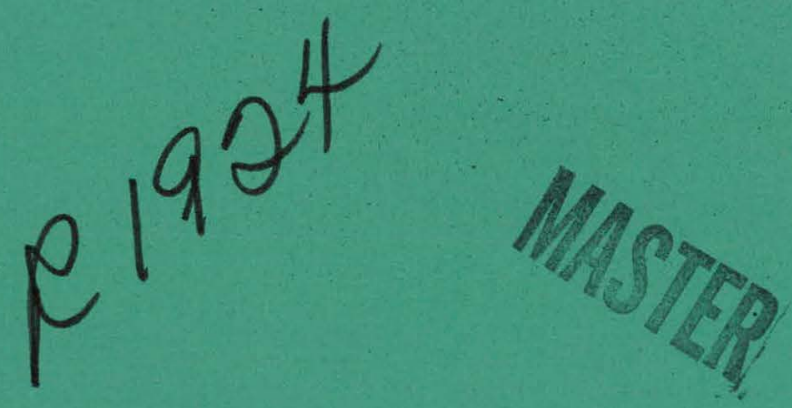

Prepared for:

U.S. Department of Energy

Office of Energy Research.

Solar Power Satellite Projects Division

Under Contract No. AC01-79ER10041

DOE/NASA

Satellite Power System

Concept Development

and

Evaluation Program 


\section{DISCLAIMER}

This report was prepared as an account of work sponsored by an agency of the United States Government. Neither the United States Government nor any agency Thereof, nor any of their employees, makes any warranty, express or implied, or assumes any legal liability or responsibility for the accuracy, completeness, or usefulness of any information, apparatus, product, or process disclosed, or represents that its use would not infringe privately owned rights. Reference herein to any specific commercial product, process, or service by trade name, trademark, manufacturer, or otherwise does not necessarily constitute or imply its endorsement, recommendation, or favoring by the United States Government or any agency thereof. The views and opinions of authors expressed herein do not necessarily state or reflect those of the United States Government or any agency thereof. 


\section{DISCLAIMER}

Portions of this document may be illegible in electronic image products. Images are produced from the best available original document. 


\section{NOTICE}

This report was prepared as an account of work sponsored by the United States Government. Neither the United States nor the United States Department of Energy, nor any of their employees, makes any warranty, express or implied, or assumes any legal liability or responsibility for the accuracy, completeness, or usefulness of any information, apparatus, product, or process disclosed, or represents that its use would not infringe privately owned rights. Reference herein to any specific commercial product, process, or service by trade name, mark, manufacturer, or otherwise, does not necessarily constitute or imply its endorsement, recommendation, or favoring by the United States Government or any agency thereof. The views and opinions of authors expressed herein do not necessarily state or reflect those of the United States Government or any agency thereof.

Avallable from:

National Technical Inforwation Service (NTIS)

U.S. Department of Conmerce

5285 Port Royal Road

Springfield, Virginia 22161

Price: Printed Copy:

$\$ \$ \$ 8: 00$ 
DOE/ER/10041-T11

Dist. Category UC-13

\section{Satellite Power System (SPS) Public Outreach Experiment}

December 1980

Prepared by:

Sherry R. McNeal

PRC Energy Analysis Co.

Los Angeles, CA 90024

Under Contract AC01-79ER10041

Prepared for:

U.S. Department of Energy

Office of Energy Research

Solar Power Satellite Project Division

Washington, D.C. 20585

DOE/NASA

Satellite Power System

Concept Development

and

Evaluation Program

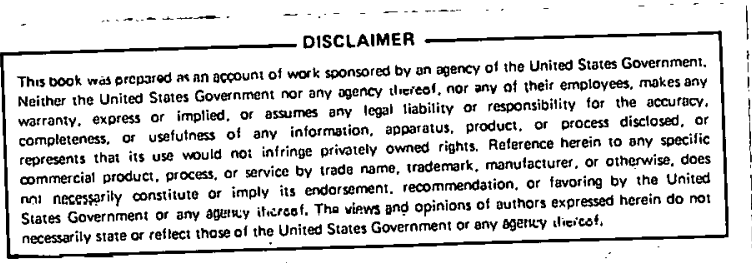

GRTดIBUTIOH OF THS DOCUMEET IS UNLIMITE 
FOREWORD

The Department of Energy (DOE) is considering several options for generating electrical power to meet future energy needs. The satellite power system (SPS), one of these options, would collect solar energy through a system of satellites in space and transmit this energy to Earth. A reference system has been described ${ }^{l}$ that would use photovoltaic cells to collect the solar energy, convert it to microwaves, and transmit the microwave energy via a directive antenna to large receiving/rectifying antennas (rectennas) on Earth. At the rectenna, the microwave energy would be converted into electricity for use in the utility grid.

A three-year Concept Development and Evaluation Program (CDEP) was begun in fiscal year 1978 by the SPS Project Division (SPSPD)... "to develop by the end of 1980 an initial understanding of the technical feasibility, economic practicability and the social and environmental acceptability of the sPs concept." 2

To ensure that the "initial understanding" developed in CDEP was as complete as possible, an approach was implemented which emphasized wide participation and open communication. Workshops, consisting of leading investigutors in a particular field, met to scope studies most beneficial to SPS and to review progress. Recommended studies were implemented by those recognized throughout the U.S. for their competence and independence whether from universities, government or private industry. Assessment study reports were peer-reviewed without exception. Study results were presented at program review meetings open to the public and the final reports were widely distributed. This ensured that each report (approximately 100 were prepared during CDEP) was seriously considered by several people not associated with the SPSPD and that at least some attention was given to each report by several hundred to several thousand others.

To further expand participation in the public arena, an outreach experiment was conducted involving over 9000 individuals from three diverse public interest groups. The major objective of the outreach was to identify public concerns through a process which would enable individuals to ask questions and to express their views. The experience has been successfully concluded; the results are reported herein.

\footnotetext{
1. Satellite Power System (SPS) Reference System Report, Department of Energy, DOE/ER-0023, October 1978.

2. Satellite Power System (SPS) Concept Development Evaluation Program Plan (July 1977 to August 1980), Department of Energy, DOE/ET-0034, February 1978.
} 


\section{ACKNOWLEDGEMENTS}

The outreach experiment was largely conducted by three public interest groups. These groups and the key contributors from each are:

- Citizen's Energy Project: Ken Bossong

Scott Denman

Jan Simpson

- L-5 Society:

Carolyn Henson

Annita Harlan

Tames Bennett

- Forum for the Advancement of Students in Science and Technology:

Alan Ladwiọ

Leonard David

Lori Kapner

Sincere appreciation is extended to each of these individuals and to their constituents who responded to the outreach effort.

Acknowledgement is also due to the peer-reviewers of this report. Their comments were a valuable contribution to the final product. They are:

Dr. Jill N. Nagy

Psychology Department

Loyola University

Chicago, Illinois

William J. Cirone and

Barbara Margerum

Center for Community Education and Citizens Participation

Santa Barbara, Ca.

Cricket Coffman

Tennessee Valley Authority

Citizen Action Office

rnoxville, Tëıu.
Dr. John Edwards

Psychology Department

Loyola University

Chicago, Illinois

Helen Clement

Southern California Association of Governments

Loo Angeles, Cä.

Dr. William R. Bernhagen

Dirertor

Wisconsin Energy Fitension Service Madison, Wis. 
To improve the results of the Satellite Power System (SPS) Concept Development and Evaluation Program, an outreach experiment was conducted. Three public interest groups participated: the L-5 Society (L-5), Citizen's Energy Project (CEP), and the Forum for the Advancement of Students in Science and Technology (FASST). Each group disseminated summary information about SPS to approximately 3,000 constituents with a request for feedback on the SPS concept. The objectives of the outreach were to (1) determine the areas of major concern relative to the SPS concept, and (2) gain experience with an outreach process for use in future public involvement.

Due to the combined efforts of all three groups, 9200 individuals/ organizations received information about the SPS concept. Over 1500 recipients of this information provided feedback. The response to the outreach effort was positive for all three groups, suggesting that the effort extended by the SPS Project Division to encourage an information exchange with the public was well received.

The general response to the SPS differed with each group. The L-5 position is very much in favor of SPS; CEP is very much opposed and FASST is relatively neutral. Regarding the Reference System, I-5 is critical, encouraging consideration of extra-terrestrial resources and other alternative concepts. CEP is critical of the SPS concept, opposing any further development. FASST respondents raised issues about the vulnerability and control of SPS. Regarding societal effects, FASST and CEP respondents are concerned about the centralization/decentralization issue. The centralization inherent in the SPS concept is not favored by either group. Military implications of SPS are a major societal concern of L-5 respondents. All three groups agree that the major environmental concern is the possible effect of microwave radiation on the environment.

The outreach experiment was successful with respect to its major objective - the identification of public concerns. All three groups, with different methods and approaches to their constituencies, provided considerable information regarding their concerns about SPS - valuable information in directing future research efforts. Many of the concerns identified are common amongst the three groups; however, they differ in their priority. 


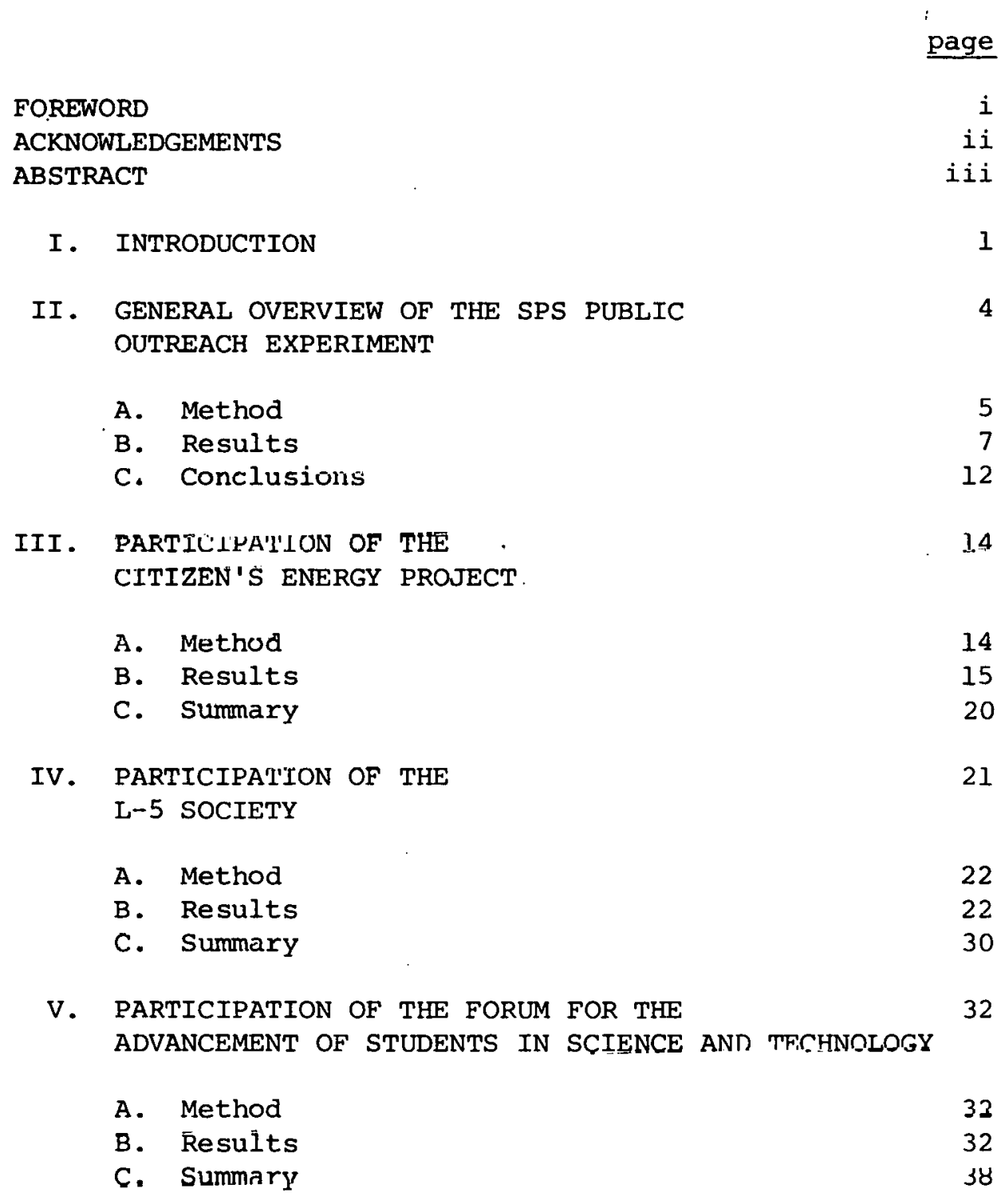

APPENDIX A: SOME QUESTIONS AND ANSWERS ABOUT THE SATELLITE POWER SYSTEM 
NO.

Exhibit 1:

Exhibit 2:

Exhibit 3:

Exhibit 4:
TITLE

SPS Participatory Technology Process

Methodological Steps of the

SPS Public Outreach Experiment

SPS Questions and Answers Ranked in the

Top Ten by the Three Participating Groups

Responses to SPS Questions and Answers

by the L-5 Society
PAGE

3

6

10

29 


\section{INTRODUCTION}

The Satellite Power System (SPS) is an advanced technological concept with a potential impact of international proportions. It raises environmental, institutional and technological issues of public concern. Open and thorough treatment of questions and concerns which incorporate public involvement, is a necessary, but by no means sufficient condition for public acceptance of SPS; and public acceptance of SPS is a necessary (although again insufficient) condition for its ultimate realization.

There are several other factors which underline the necessity for public participation: ${ }^{3}$

- Requirements for direct public involvement in project review and decision processes in environmental legislation.

- Passage of federal, state and local laws and regulations to control and reverse environmental degradation, such as the clean Air Act and the National Environmental Policy Act.

- Public realization of limitations in the environment's capacity to absorb impacts of an industrial society.

- Passage of public disclosure legislation, such as the Freedom of Information Act.

- Trends in the judicial/regulatory arena which provide citizens a legal means to express their interests.

- General decline in trust and goodwill towards government.

- Rise and prominence of public interest organizations.

- Growth of single issue political organizations.

Recent trends in public opinion polls suggest that public perceptions of the economy, energy situation and the environment have changed from optimism about an unlimited future towards a new sense of lowered expectations and a limited future. ${ }^{4}$ Scientific research and technological developments are perceived as mixed blessings and at least some of the public seems unwilling to accept environmental risk for high economic or energy growth. In general, a trend away from centralization of institutions and decision-making in the U.S. is evident. 5 States are assuming more power, communities and neighborhoods are

3. Bachrach, A. Satellite Power System: Public Acceptance, Department of Energy, DOE/HCP/R 4024-04, October 1978.

4. Klineberg, Stephen L. The Social Acceptability of Satellite Power Systems: A Preliminary Exploration, Rice University, Working Paper.

5. Naisbett, John. Satellite Power System (SPS) Centralization/Decentralization. Department of Energy, DOE/HCP/R 4024-9, October 1978. 
increasing their influence and control and a militant new regionalism is likely in the next decade. There is a growing institutional diversity in approaches to problem solving (including those related to energy), reflected in an increasing use of the referenda or initiative process. There is also a trend toward a multi-option society, rather than an either-or society, reflected in an increasing interest in "appropriate scale" technologies rather than accepting technologies based on economies of scale alone.

These trends suggest that public acceptance of SPS or any large technology may not be easily obtained. The greatest assurance for obtaining public acceptance, however, lies in a program of public involvement in which public concerns can be identified and addressed in the developmental process.

During the SPS CDEP, public involvement has been an integral part of the Participatory Technology Process (PTP). The major features of this approach are shown in Exhibit 1. The activities undertaken and issues addressed have been guided by workshops of nationally known investigators. The studies themselves have been conducted by private contractors, universities, government laboratories, or other government agencies; the intent being the best possible study and the widest range of thinking about SPS. Every assessment study report has been peer reviewed. Generally, two peers from government (independent of SPS), two from industry and two from the university community have reviewed reports. Study results have been reported at annual program review meetings open to the public, with interaction between presenters and participants. The reports have been printed by the Department of Energy and widely distributed in the United States and other nations.

The Active Feedback Outreach further expands public participation. During the CDEP, a public outreach experiment was conducted. Three public interest groups participated: the L-5 Society, the Citizen's Energy Project, and the Forum for the Advancement of Students in Science and Technology. Each group disseminated information about SPS to approximately 3,000 of their constituents with a request for feedback on the SPS concept, emphasizing their questions and concerns.

This report summarizes the public outreach experiment. Section II is an overview, including the methodology, major results obtained, and general conclusions. Sections III, IV, and V provide more detail on the specific methods used, results obtained, and conclusions drawn by each qroup. Appendix A is a compilation of 44 questions asked by participants in the experiment together with answers provided by SPSPD representatives. 


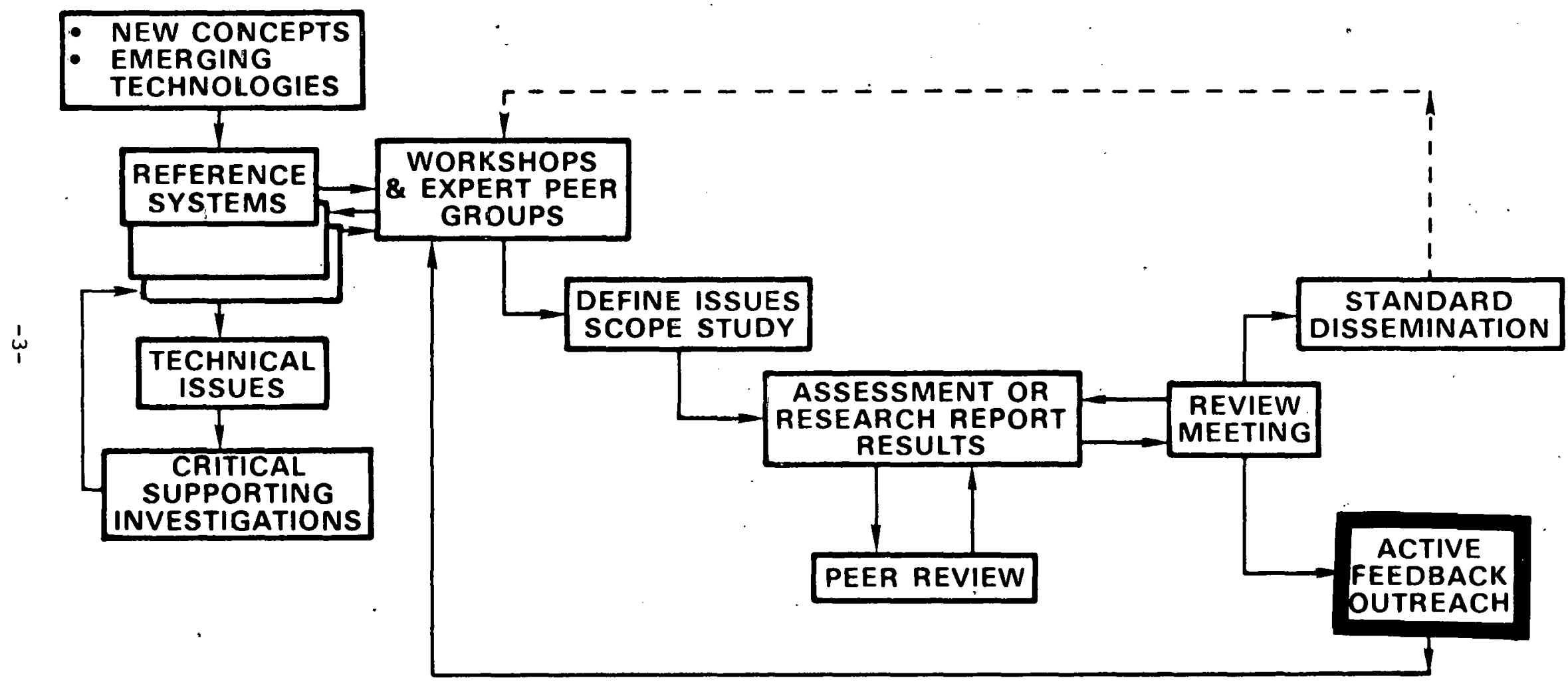

EXHIBIT 1

SPS PARTICIPATORY TECHNOLOGY PROCESS 
The outreach experiment was an initial effort to acquire feedback about the SPS concept from the public. Two major objectives of the outreach were:

- to identify public concerns and questions about the SPS.

- to gain experience in an outreach process for use in the development of future SPS public involvement activities.

Three public interest groups participated in the experiment. They were:

- Citizen's Energy Project (CEP) : a tax-exempt research and advocacy organization. Its primary interests are energy policy and appropriate technology. Since 1973, CEP has published 150 books and reports on alternative energy snurres, antipoverty programs and enviuimululal issues. CEP favors decentralized solar technologies.

- L-5 Society (L-5): an international memebership organization that supports space industrialization and advocates the development of human settlements in space. The goal of the organization is to get tens of thousands of people living and working in space before the end of the century. L-5 sponsors conferences and publishes the L-5 . News (monthly).

- Furum for the Advancement of Students in Science and Technology (FASST): a national network of individuals and organizations supporting active student participation in scienne, mnliey developmont, rescareh and new applicaliuns in sclence. H'AS'S' programs are available to postsecondary students, government agencies, industries and organizations. FASST publishes a quarterly news magazine, FASST NEWS, and offers a press release service and research support. and consulting services. Prior to the outreach, both $L-5$ and CEP had demnnatrated a position on SPS. L-5 was in favor of the continued development of SPS; CEP was opposed to any development of SPS. With the selection of these two groups for participation, one in favor and the other opposed, it was felt that public concerns, from both a pro and con perspective, could be identified. FASST had not taken a position on SPS prior to the outreach. However, in an earlier phase of the CDEP, FASST had completed a student 
participation study ${ }^{6}$, the objective being to assess various methods and procedures that might prove suitable to involve students in the discussion of SPS issues: Some ideas and suggestions which resulted from this study were integrated into the experimental effort.

Each group was contacted and asked to participate in the outreach experiment. Each agreed to initiate, organize and monitor a process of information exchange about the SPS concept with their constituents under contract with PRC Energy Analysis Company. The program began in January 1979 and is completed with this final summary report.

A. METHOD

The steps involved in the outreach program are presented in Exhibit 2. Each group independently summarized about twenty SPS reports with emphasis on important points and issues thought to be of special interest to their respective constituents. At no time were these summaries edited by DOE, PRC, or anyone other than those deemed appropriate by the groups themselves. Each group distributed their SPS summaries to approximately 3,000 constituents with a request for feedback. Responses were collected, analyzed, summarized, and submitted in reports to PRC. Each group also contacted several representative individuals for a more detailed response to the SPS concept. The methods adopted for the preparation and distribution of the summaries and request for feedback were independently chosen by each group.

As responses were collected and analyzed, each group identified the questions asked by their constituents relative to the SPS concept and outreach process. These were combined into 44 questions in five topical areas: the SPS reference system, the comparative analysis, the environmental effects, the societal effects and the DOE program. Answers were obtained from the DOE/NASA principal investigators responsible for related assessment and research studies. After editing by PRC, the questions and answers were reviewed by task managers of SPS research and development projects for accuracy. The final set of questions and answers are provided in Appendix $A$ of this report. DOE printed the questions and answers in a document entitled "Some Questions and Answers about the Satellite Power system" and distributed the document to respondees of all three groups. 7

6. FASST (A. Ladwig and D. Leonard) Satellite Power system Student Participation. Prepared for the Department of Energy Satellite Power System Project Division, DOE/HCP/R 4024-06, October 1978 .

7. L-5 did not request names and addresses of respondees; therefore the original membership. list of approximately 3,200 was used. 


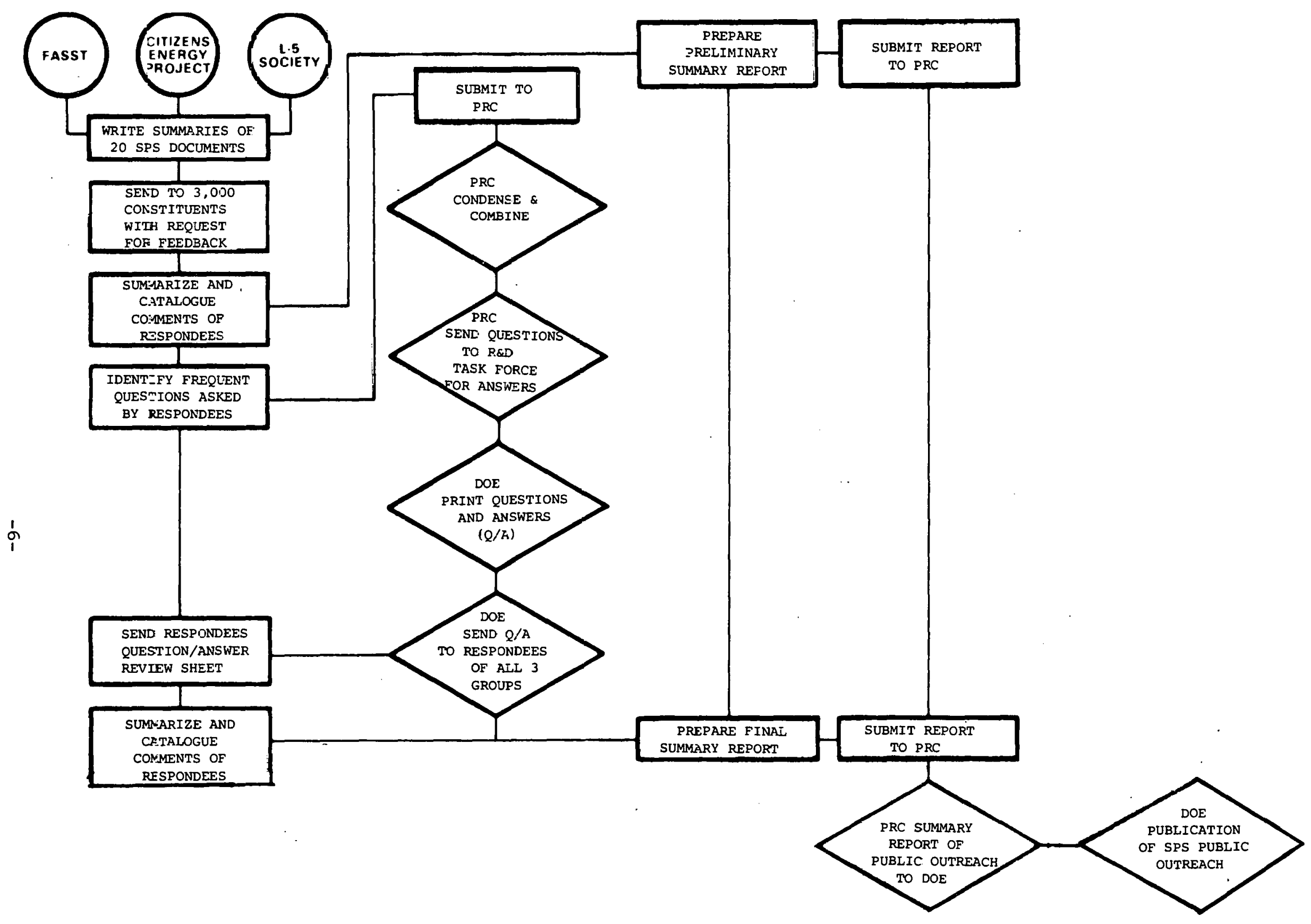

EXHIBIT 2

METHODOLOGICAL STEPS OF THE SPS PUBLIC OUTREACH EXPERIMENT 
Concurrently each group prepared and sent a review sheet and cover letter to their respondees to serve as notification that the Question/Answer document was forthcoming and to solicit comments on it.

\section{B. RESULTS}

Due to the combined efforts of all three groups, 9200 individuals/ organizations received information about the SPS concept. Over 1500 recipients of this information provided feedback. Following is a summary of the methods used and the concerns identified by each group. A detailed presentation of the methods used and the results obtained is provided in the next three sections of this report.

1. Method of Outreach

a. Each group independently established its own method of preparing and distributing the summaries of SPS reports.

- The L-5 s.taff and CEP staff prepared their own summaries, whereas FASST involved students in the process.

- FASSTT and L-5 made one initial contact with their constituents, sending all the SPS summaries in one mailing; whereas CEP sent SPS summaries in five different mailings.

- FASST recipients received a considerable amount of information all at one time, CEP recipients received small packets of information several times, and $L-5$ recipients received one condensed summary.

b. All three groups sent cover letters with their mailings, informing constituents of the outreach and requesting their participation.

c. The three groups differed with respect to the degree of structure imposed on responses, and the emphasis of issues on which feedback was requested.

- CEP used both a non-structured and semi-structured response form. The first two mailings included a request for comments. In the last three mailings, response forms with open ended questions were included.

- FASST used a response form which asked for specific demographic information, and generally asked for comments and questions about the SPS concept.

- L-5 used a two page response from with both open ended and close ended questions. This response form was the most structured of the throe.

- CEP and FASST requested qualitative feedback on their summaries (e.g. . good/bad; biased/unbaised). L-5 did not. 
- Feedback requested by L-5 addressed critical issues involved in the implementation of SPS, whereas CEP addressed critical issues involved in the concept itself.

- CEP was particularly concerned about objectivity in the summaries, aware that an evident bias in favor of, or in opposition to, sPS would be discerned by recipients. An approximately equal number of responses accused CEP of being pro and anti SPS, so objectivity seems to have been obtained.

- L-5 asked such questions as who should research, construct and own the SPS, what areas of research need more emphasis, what reference design alternatives should be given more emphasis and what government agencies should play a role in SPS development.

- CEP asked opinions about the economics, the environmental issues, the soclal concerns, the impact of centralization, health and safety issues, and preferable alternatives.

- Both CEP and L-5 asked who shuuld own and control the SPS. A comparison of responses is not possible however, since the majority of CEP respondenta gaid 3PS slivuld not be developed rather than stating who should own or control it.

- FASST requested no structured feedback on the SPS concept, requesting only comments or questions. The response form did however ask respondents to rate the method of outreach (i.e., summary preparation and distribution and request for feedback) as a means to both inform and involve students in the SPS concept development process.

d. The response rate was the highest for the L-5 society, which received 850 responses. CEP received 383 and FASST received 306. Two factors might account for the higher response rate of the L-5 Society. First, this organization's principal interest is space colonization, and SPS may be viewed by its members as a catalyst for space cólonization: therefore SPS is a salient issue to L-5 members. Second, L-5 recipients received the most concise input. Effort needed to read and reply was therefore less extensive than that needed by FASST and CEP recipients.

2. Values and Concerns

a. Reference System

$L-b$ is critical of the Reference System, encouraging consideration of extra-terrestrial resources. and other system alternatives. CEP is critical of the SPS concept, opposing any development. FASST respondents raised issues about the vulnerability and control of SPS. 


\section{b. Societal Effects}

FASST and CEP respondents are concerned about the centralization/decentralization issue. Military implications are the major societal concern of L-5 respondents; however, respondents are divided in their opinions regarding the possible good and bad effects of SPS being used as a weapon.

\section{c. Environmental Effects}

All three groups agree that the major environmental concern is the possible effect of microwave exposure on human health and the environment.

d. The Outreach Effort

The response to the outreach effort by respondents in all three groups was positive. The opportunity to provide seedback and input to the SPS concept development was widely appreciated. However, there was skepticism voiced by some respondents in all three groups about whether or not public input would be effectively utilized.

\section{e. General Response to SPS}

The L-5 position favors SPS. As an organization which supports space ventures and technological development, SPS represents a door into the space frontier. The CEP is opposed to SPS. The two major reasons given for opposing it are the trend toward centralization to which SPS is expected to contribute, and the cost of SPS which could reduce funds available for terrestrial solar alternatives. The FASST position on SPS is relatively neutral. Their focus has been on the process of outreach and an effort to include student participation in the development of an advanced technological system.

\section{Priority Concerns}

The general issues addressed in the top ten questions as ranked by each group are presented in Exhibit 3, which represents to some extent, 


\begin{tabular}{|c|c|c|c|c|c|c|}
\hline \multirow{2}{*}{$\begin{array}{c}\text { RANK } \\
\text { ORDER } \\
1\end{array}$} & \multicolumn{2}{|r|}{ CITIZEN'S ENERGY PROJECT } & \multicolumn{2}{|r|}{ L-5 SOCIETY } & \multicolumn{2}{|c|}{$\begin{array}{c}\text { FORUM FOR THE ADVANCEMENT } \\
\text { OF STUDENTS IN SCIENCE AND TECHNOLOGY }\end{array}$} \\
\hline & $(I V-3)$ & OPPORTUNITY COSTS & $\therefore(I I-1)$ & MIEROWAVE BIOEFFECTS & $(\pi V-\varepsilon)$ & INTERNATIONAL PARTICIPATION \\
\hline 2 & $(I I-6)$ & TERRESTRIAL SOLAR TECHNOLOGY & $(T-7)$ & $\begin{array}{l}\text { DEPLETION OF } \\
\text { EAZTH'S RESOURCES }\end{array}$ & (III-I) & MICROWAVE BIOEFFECTS \\
\hline 3 & $(I I I-1)$ & MICBOWAVE BIOEFEECTS & $(I V-6)$ & MILITARY IMPLICATIONS & $(I-2)$ & SPS VULNERABILITY \\
\hline 4 & $(I V-1)$ & CENTPALIZED POEER & $($ arv-3) & OPPORTUNITY COSTS & $(I-B)$ & $\begin{array}{l}\text { STUDENT OPPORTUNITIES } \\
\text { FOR INVOLVEMENT }\end{array}$ \\
\hline 5 & $(I V-6)$ & MILITARY IMPLICATIOAS & $(I-20)$ & $\begin{array}{l}\text { ALTERNATIVE REFERENCE } \\
\text { SYSTEMS CONCEPTS }\end{array}$ & $(I V-6)$ & MILITARY IMPLICATIONS \\
\hline 6 & (III-6) & $\begin{array}{l}\text { UTILIZATION OF } \\
\text { GEOSTATIONARY ORBIT }\end{array}$ & $(y-6)$ & ENERGY SELF-SUFFICIENCY & $(v-3)$ & $\begin{array}{l}\text { PUBLIC INFORMATION } \\
\text { AVAILABILITY }\end{array}$ \\
\hline 7 & $(I I I-2)$ & $\begin{array}{l}\text { ATMOSPHERIC HEATING } \\
\text { EFFECTS }\end{array}$ & $(7-5)$ & $\begin{array}{l}\text { CONTINUATION OF SPS } \\
\text { RESEARCH AND DEVELOPMENT }\end{array}$ & $1 I-10 \mid$ & $\begin{array}{l}\text { ALTERNATIVE REFERENCE } \\
\text { SYSTEM CONCEPTS }\end{array}$ \\
\hline 8 & $(I I I-3)$ & DAMAGE TO OZJNE LAYER & $([v-1)$ & CENTRALIZED POWER & $\mid I I-6)$ & TERRESTRIAL SOLAR TECHNOLOGY \\
\hline 9 & (III-5) & $\begin{array}{l}\text { DISRUPTION OE } \\
\text { COMMUNICATION SYSTENS }\end{array}$ & $(I I-2)$ & NET ENERGY ANALYSIS & $(\mathrm{IV}-1)$ & CENTRALIZED POWER \\
\hline 10 & $(I I-7)$ & IMPACT ON LABOR MARKET & $(z v-9)$ & $\begin{array}{l}\text { CONIROL AND MAINTENANCE } \\
\text { OF SPS }\end{array}$ & $(I V-7)$ & $\begin{array}{l}\text { DEPLETION OF EARTH'S } \\
\text { RESOURCES }\end{array}$ \\
\hline
\end{tabular}

- See Appendix A for complete question ard answer identified by the number in parentheses.

EXHIBIT 3

SPS QUESTIONS AND ANSWERS RANKED IN THE TOP TEN IN TEPMS OF IMPORTANCE BY THE THREE PARTICIPATING GROUPS 
a priority of concerns of each group. ${ }^{9}$ For example, CEp is particularly concerned about the opportunity $\operatorname{costs}^{10}$ of SPS, the possiblity of breakthroughs in terrestrial solar technology eliminating the need for SPS, and the possible microwave bioeffects. L-5 is concerned also with the possible microwave bio-effects, depletion of Earth's resources (reflecting the advocacy of the use of other space resources such as the Moon and asteroids) and the potential military implications of SPS. FAAST is interested in the possiblities of international participation of SPS development, and concerned with :icrowave bioeffects and SPS vulnerability.

Common questions ranked in the top ten by all three groups address the topics of microwave bioeffects, whether there is a need for centralized power, and military implications of SPS. Questions in the top ten which are unique to CEP are those concerning the impact on the labor market, atmospheric heating effects, and communications disruption. Questions which are unique to L-5 concern net energy production, how SPS improves energy self-sufficiency, and continuation of SPS R\&D. Questions which are unique to FASST concern SPS vulnerability, international participation in SPS development, and public information availability.

4. Responses to the Questions and Answers Document

The L-5 Society received 285 responses to the SPS Question/Answer $(Q / A)$ document. In general, these responses were positive and the majority found the answers to the questions to be satisfactory.

Unfortunately, due to some administrative problems at DOE, the $\mathrm{Q} / \mathrm{A}$ document was not mailed at the scheduled time to CEP and FASST respondees. This delay is considered to be a major factor in the poor response to the request. for feedback in both groups. Less than two dozen of the CEP respondees provided feedback on the $Q / A$ document; none were received from FASST. (It should be noted that by the time the $Q / A$ document was mailed to FASST respondees, the academic year was over.) Comments by CEP respondees were generally critical of the document.

9. It should be noted that these rankings have been provided by the staff of each group, and have not been reviewed by constituents.

10. Opportunity costs are those costs which reduce the development potential or funding of other promising technologies. 


\section{CONCLUSIONS}

The objectives of the outreach experiment were: 1) to identify public concerns and 2) to gain experience for future outreach efforts. With regard to both of these objectives, the outreach experiment was successful.

Questions, concerns and benefits regarding the SPS concept, as perceived by the respondents, were identified. No concerns which had not been previously identified through other mechanisms in the Participatory Technology Process were found. Two studies, however, were initiated to more adequately respond to expressed public concerns. One study addressed the question of insurance (both liability and loss) and another addressed the lifetime of the satellites in yeostatlonary orbit.

With regard to the second objective, the experiement provided considerable information about a communicative process in the early development of an advaiced lechnological concept such as SPS. The response to the outreach effort was positive for all three groups, suggesting that the effort extended by the SPS Project Division to encourage information exchange with the public was well received. The outreach effort also generated requests for additional information from the constituents of all three groups, and many respondents expressed interest in continued involvement.

There are, however, several aspects of this process which deserve furller consideration in any future outreach effort. One of these is the clarification of objectives. The major objective of the outreach was to identify public concerns, providing a source of information valuable in defining issues and scoping studies. However, in the request for feedback initiated independently by each group, a general reaction to SPS was often indicated (i.e. in favor or opposed to). These type of data are susceptible to misinterpretation as an opinion poll or attitude survey. However, the outreach process (as reflected in this experiment) is not a valid methoduluyy fur ascertaining attitudes or opinions. It lacked two important criteria, among others: standardization and representativeness. Regarding standardization, each of the three participating organizations worked independently in the development and implementation of the outreach experiment. As a consequence, 
the kinds of information received, both quantitatively and qualitatively, are different for each group. Comparisons are therefore not appropriate. Regarding representation, it is not known to what extent these groups and the responding constituents represent a larger public. To avoid misinterpretation, it is important to insure that the objectives are clear, understood, and continually emphasized during the entire process.

Similarly, the intentions for utilization of public input should be clearly stated and understood by participants. Several respondents in the outreach experiment were cynical regarding the use of public input or if in fact it would be used at all. Public input resulting from the outreach was used during the CDEP by the SPS Project Division to define issues and scope other studies (such as the insurance study and orbit decay of geostationary orbits). Public input is also valuable in scoping any future studies to insure that public. concerns are addressed in the developmental process; this should be made clear to future participants.

A final point to be considered in future outreach efforts is the conflict between participants that may exist prior to, or arise during, the course of the outreach. For example, there are competing values and preferences with respect to SPS development between CEP and L-5. CEP is coordinating a new national coalition to oppose development of SPS technology, known as the Coalition Against Satellite Power System (C.A.S.P.S.). L-5 is actively promoting SPS R \& D. It may be beneficial to engage representatives from such groups in activities which attempt to resolve conflicts, or at least to identify more specifically the areas of agreement and disagreement. 


\section{A. METHOD}

The method of outreach used by the Citizens Energy Project (CEP) consisted of the following activities:

- Twenty-two summaries of SPS reports were prepared by the CEP staff, averaging 3-4 pages in. length.

- A mailing list was compiled to include a broad cross-section of constituencies. Press releases were sent to some 50,000:persons in general mailings. Respondents to the press releases and announcements were placed on the mailing list. In addition to those rospondents, the mailing list included solar/ant1-nuclear/ environmental organizations, small solar businesses, local and state government officials; individual activisls involved in energy policy issues, labor spokespersons, and miscellaneous groups. The final list was comprised of 3,000 individuals and organizations.

- The summaries were mailed in series approximately three weeks apart. Each mailing included a set of two to six SPS report summaries and a cover letter introducing the contents of the packet, providing an update on the project, and a requast for feedback. The first two mailings urged the reader to submit general written comments on the SPS summaries. The last three mailings included a response form. The third mailing inoluded a two page response torm consisting of 26 open ended questions, which addressed several general issues of the SPS concept. The last two mailings included a one page response form consisting of open ended questions which addressed more specifically the issues relevant to the summaries accompanying the response form.

- Telephone interviews were conducted with 30 people in various fields to solicit their opinions and concerns about the proposed solar power satellite system.

- Written comments were analyzed on the basis of topical areas, which were related in part, although not entirely to the individual summaries. The frequency of comments related to specific issues was noted as well as respondents' positions relative to the issue. Responses on the response form were analyzed by identifying and tallying all responses to each question. Telephone interview responses were analyzed in a manner similar to written comments. 
- A final report of outreach activities and results, prepared by the CEP staff, was mailed out to persons who offered comments during the preceding activities.

- The document entitled "Some Questions and Answers About the Satellite Power System" was sent by DOE to the over 400 CEP participants/respondees. (The questions and answers from this document are presented in Appendix A.) With anticipation of this mailing, CEP sent a letter announcing the forthcoming document. Accompanying this letter was a response form requesting feedback on the CEP final report and the question/Answer document.

- Several articles on the results of the outreach experiment were prepared and submitted for publication to appropriate periodicals.

\section{B. RESULTS}

Responses to the summaries totaled 382; however, 20-25 percent of the respondents submitted more than one set of responses making actual response rate about 10 percent. Thirty five percent (133) of these responses were in the form of written comments.

The geographic distribution of responses was similar to the population distribution of the United States, with the largest number coming from California, New York, Pennsylvania, Massachusetts, Michigan, and Illinois. One significant exception was Washington, D.C. Over 400 summaries were mailed to individuals and organizations in this area. Only five responses were received. A broad range of occupational backgrounds were represented. Respondents included housewives, biologists, accountants, teachers, government officials, students, engineers, economists, and community organizers. State utility regulatory commissioners and labor representatives were two audiences appivached that did not resmond in any significant number. The largest number of responses came from anti-nuclear and pro-solar citizen groups. The written comments, answers on the response forms, and telephone interviews all indicate similar conclusions. Therefore, a selection of response data from all three types of responses have been integrated in the following presentation. 11

11. In those cases where the data are reported in terms of percentages, it should be noted that: 1) the total number of responses on which the percentages are calculated is not a constant, as all individuals did not respond to all questions; therefore percentages are based on the number of those responding to the item in question; 2) percentage figures may not total $100 \%$ in cases where response categories are not mutually exclusive. This ic partisularly true with regard to the written comments. Percentages for written comments are based on the total. number of written responses, 133. 


\section{The Outreach Program}

In general, respondents were pleased with the government's effort to request their input on the SPS concept. A vast majority specifically stated their appreciation for both receiving the reports and having the opportunity to contribute their thoughts on the SPS. However, some questioned whether this information would be used in a meaningful way.

- In over 80 percent of the written responses, solicitation of written comments, suggestions, and concerns by DOE through CEP, was considered a positive step in obtaining citizen input into the governmental decision making process. Ten perrent were pleaocd to find a yuvernment agency taking the initiative to involve the public before the project is in full development. Ten percent concurred that DOE should be recognized for its SPS citizen involvement. Ten percent voiced concern over whether DOE would utilize and incurporate the responses into the SPS decision-making process. Twenty percent were pleased with the effort but concerned about the feasibility of SPS and therefore wished no further public expenditure on the concept.

- Of 30 telephone respondents, six saw the assessment as a positive step by $D O E$, suggesting it should be applied to other agencies and programs. Seven had doubts as to how the results would be used.

- When asked for an opinion regarding CEP's involvement, over 100 respondents gave positive answers, including "good" and "excellent". Nine respondents questioned the utilization of the results and ten indicated the possibility of bias in the organization.

2. About the Summarios

Most respondents thought the summaries were well done, interesting,

and presented a good balance of opposing perspectives.

- Sixty seven percent of the written comments indicated that the reports gave a good balance to opposing perspertives witli liunest statements about what is known and relevant to SPS. A few considered them biased one way or the other. A largc majority found the summaries to be educational and factual. Ten pcrcont fulb uertain issues were not covered well enough (e.g. comparative assessment, the "real cost", net energy analysis).

- Responses to questions on the response form related to the number of summaries read, indicated that the majority had read all the summaries received, found no factual errors or 
misleading statements, and thought they were well done, interesting and easy to read. Forty-two respondents (11\%) thought the summaries were biased.

\section{Decentralization/Centralization}

A major concern of the majority of respondents is that SPS is a highly centralized technology that is considered inconsistent with their view of the "inherently decentralized" nature of solar technologies.

- Regarding written comments, sixty-seven percent identified this issue as a major concern. There was unanimity over concern that SPS development would foster continued centralization and corporate government control of energy supplies, trends which are viewed in a negative light. Relative to this concern was the fear that funds would be pulled from other decentralized systems. A few felt SPS would be a decentralized energy source because of the rectennas scattered throughout the country.

- Reasons given for being against centralization include the following:

- SPS would impede individual freedom of choice and community decentralized systems.

- Centralized systems are militarily more vulnerable than decentralized systems.

- Relatively poor employment potential is characteristic of centralized systems.

- Adverse environmental impacts have historically occurred with development of centralized industrial and energy systems.

- Centralized systems pose a potential danger to visions for a democratic future America.

- A reason given for pro-decentralization is that it is condusive to innovative social change, creative solar energy usage, and community self-reliance.

- Telephone respondents also indicated that a primary concern was the increased centralization which would come with SPS. Thirteen out of thirty respondents felt centralization would be a negative impact.

- When asked on the response form, "What are the primary social concerns you see with the SPS?", 388 of 150 respondents replied the failure to promote decentralization. Seventy eight percent of 153 respondents indicated that they thought the SPS would have an impact on an increased trend toward centralization, which is undesireable in their view. Twentynine percent of 147 respondents indicated the issue of decentralization as an issue of highest priority in reaching conclusions about the SPS. 


\section{Economic Considerations}

A major concern of the majority of respondents is the perceived

high cost associated with the development of SPS.

- Nearly all written responses contained some reference to economics: A large majority stated preference for allocating funds to benign, renewable energy resource development. Ten percent noted the absence of an opportunity cost analysis in the reports. Several respondents expressed the sentiment that SPS R \& D was being promoted to bail out an industry (the aerospace industry) that had come upon hard times.

- Thirty-three percent expressed concern over who would control and benefit from SPS. Ten percent raised questions about the net energy gain derived from SPS as compared to other systeme, arguing that terrestrial systems would require less energy input than SPS to develop and maintain, at a lower cost.

- The capital drain of an SPS was one of two issues of greatest signdflcance to telephonc respondents. They felt SPS would divert money from more appropriate technologies.

- When asked for an opinion regarding the economics of SPS development on the response form, 698 of 162 respondents indicated it was too costly and may take away from other alternatives. Twenty-five respondents said SPS was economically unsound.

- When asked who should own the SPS if developed, $23 \%$ of 148 respondents said it should not be developed, $13 \%$ said the U.S. government, 118 said the United Natinns and 128 said the people. When asked who should control SPS, if developed, $10 \%$ said an international consortium, $10 \%$ said the people, and $8 \%$ said private industry.

\section{Environmental Effects}

The majority of respondents named microwave radiation as the

major environmental concern. Problems are perceived for the SPS microwave power transmission system, impacts on human health, local ecosystems, and the atmosphere. Aside from the issue of microwaves, respondents varied in their emphasis on other environmental impacts. Concerns which were mentioned included land use, ozone depletion, occupational health and safety, depletion $\mathrm{OF}$ scarce mincrals and ndtural resources, heating the atmosphere by rocket launchings, rectenna disruption of surrounding ecosystems, air, water and noise pollution, climate effects, vulnerability, sabotage, boomtowns, communication interfcrence, use as a weapon, relocation of industrial and population centers, out of control technology, political dissension and failure/accidents. 


\section{International Concerns}

The major international concern expressed by respondents was

the military implications of SPS.

- Sixty percent of the respondents who submitted written comments were concerned about the military implications of SPS. (No written comments shed favorable light on this topic). Respondents expressed concern that it would be used as a strategic military weapon which could result in balance-of-power problems in the international community. The vulnerability of the SPS was also an expressed concern. Internationalizing SPS was thought to be difficult, necessary and helpful in creating worldwide cooperation.

- When asked what impact SPS development would have on international relations, 40 percent of the respondents said it would be a point of controversy, and 12 percent indicated SPS offers potential for cooperation.

7. Alternatives

The alternative suggested by the majority of respondents was decentralized energy system development. Among the specific forms were: terrestrial photovoltaics, low-head hydro, wind power, solar collectors and biomass. Many respondents indicated that conservation was essential.

8. General response to the SPS Concept

The overall general response to SPS was negative. of 382 responses, 87 percent (331) indicated opposition to the SPS concept, ranging from a sense that there were better energy options to unequivocal hostility. Eight percent (31) were neutral or undecided, saying that more study was required and five percent (20) supported SPS development.

- There was near unanimity of opposition to SPS as reflected in the written comments. Only two to three percent were in some way favorable to the concept. Forty percent wanted to see more complete and comprehensive studies on certain aspects. However, the vast majority of these were opposed to developing SPS for a number of reasons and desired all funding for the SPS to be cut.

- Regarding response form responses, when asked what reconmendations they would give to Congress regarding the SPS concept, $57 \%$ of 148 responses indicated it should be dropped, $17 \%$ indicated other alternatives should be considered, $5 \%$ suggested a continuation and/or increase in research efforts, and 48 said move ahead with commercialization. 
- When asked if the respondent's organization had taken a formal position on SPS, out of 133 responses 63\% said no, 188 said yes-opposed, and $1 \%$ said yes-in favor (but critically so).

\section{Response to the CEP Final Report on the Outreach Results}

The CEP Final Report was mailed to approximately 500 persons. A

total of 42 responses to this report was received, representing an $8.4 \%$

response rate. Generally, the comments about the report were positive. Respondents thought the document was easy to read, well-balanced, and thorough.

Respondents also submitted comments regarding the content of the report and the outreach program in general. Several respondents suggested that there should have been more discussion of the pros and cons of decentralized solar options compared to SPS. Regarding the outreach program, many respondents suggested that the outreach effort should be done over a shorter period of time; yet others suggested a longer timetable. A number of suggestions for citizen input programs were included. A majority of respondents also sug-: gested CEP should continue to monitor and report SPS development.

10. Response to SPS Questions and Answers

Due to some administrative problems, the DOE mailing of the SPS Question/Answer document to CEP respondees was delayed nearly three months following the CEP letter of announcement and request for feedback. As a consequence, less than two dozen recipients of the document responded. Five respondents submitted general comments and eighteen returned the response form. In general, the majority of respondents were critical of the document and negative towards SPS.

\section{SUMMARY}

The Citizen's Energy Project was initially uncertain as to what type of response it would receive. No previous outreach had ever been done of this audience with regard to solar power satelite technology, although it was generally assumed that most of the people on the mailing list were advocates of solar energy.

Overall, a large majority of respondents indioated oppocition to the SPS concept. While a range of reasons were provided for this opposition, the concerns that most frequently emerged were:

- the perceived problems of microwaves for SPS power transmission and its impacts upon human health, local ecosystems, and the atmosphere. 
- the concern that SPS is a highly centralized technology that is considered inconsistent with the "inherently decentralized" nature of solar technologies.

- the high economic costs associated with SPS development.

- the possible uses of SPS as a military weapon or its vulnerability as a military target.

- the availability of other energy options--notably decentralized terrestrial applications of solar.

- the miscellaneous environmental impacts of the SPS (e.g. air, and water pollution, resource depletion, and disruption of communications systems).

The preparation and distribution of the summaries by the Citizens Energy Project was generally well received while some readers expressed concesn about CEP's biases on the issue. DOE was well-regarded for (1) conducting an outreach effort at an early stage in the development of SPS technology; and (2) using an independent organization for the outreach-notably a citizen group that has some credibility with its audiences. 


\section{$\therefore$ IV. PARTICIPATION OF THE L-5 SOCIETY}

\section{A. METHOD}

The method of outreach used by the L-5 Society (L-5) consisted of the following activities:

- An eight-page summary of 20 SPS reports was prepared by L-5 and sent with a cover letter requesting feedback to the L-5 membership of approximately 3,200. A response form consisting of 12 questions relative to the SPS concept, 9 relative to the SPS program, and 8 demographic quections was enclosed.

- The World Space Center was asked to assist in the evaluation of Lite redctions to sps, due to its extensive contact with the Third World space policy makers. Several associates of the World space Center, representative of third world countries were asked to participate. These associates were contacted by mail, and if agreeing to participate, they were sent summaries of the SPS reports prepared by L-5 and the World Space Center. Dates and times were arranged for in-depth telephone interviews.

- A core group of 14 people, considered to be influential in the space community, wore sent copics of DOE 3P3 repurts which they wished to review and their comments were then analyzed by L-5.

- The document entitled "Some Questions and Answers Abuut the Satellit.e. Pnwer System" was sent by DOE to the L-S mitiluesslily. (The questions and answers from this document are presented in Appendix A.) At the same time, I-5 sent a letter to all members informing them of the forthcoming document with a request for an appraisal of each question with respect to three categories; (1) a satisfactory answer; (2) the answer seems incomplete; and (3) "I don't believe it." General commeirls were also sollcited.

B. RESULTS

\section{Response Form}

A return of 850 response forms represented a 27 percent response rate. The results of the analysis of responses are presented according to general topic classifications identified on the response form. 
a. Demographic :

General demographics of respondents include:

- Average Age: 29 (Range: 9-80)

- Sex: Male 908

Female $\quad 8 \%$

Not stated 28

- Education: High school and less 118

Some college $28 \%$

$B A$ or BS degree $33 \%$

Masters degree $12 \%$

Doctorate 108

Specialized degree $\quad 4 \%$

Not stated $2 \%$

- Nationality: U.S.A. citizen 938

- SPS related employment: Less than 18 report having a job related to SPS. Those who desire such a job in the future represent $49 \%$.

b. The Solar Power Satellite Concept

Power systems considered most desirable for the long-term

future beginning with the most preferred are as follows: extra-terrestrial solar, terrestrial solar, nuclear fusion, geothermal, hydro-electric (including tidal), and nuclear fission. Ten percent indicated two or more potentials they found equally appealing. Generally, the emphasis was less on traditional sources and more on new technology options.

The impact of power satellites on the environment was thought to be moderate by 61 percent, insignificant by 37 percent, and intolerable by 1 percent. Power systems thought to have the least environmental impact in rank order, beginning with the least perceived impact are as follows: extraterrestrial solar, terrestrial solar, geothermal, hydro-electric (including tidal), wind, and fusion. Appended comments from respondents on this issue were expansive, addressing issues of waste heat problems, heat build-up, ease of distribution, warnings about the misuse of labor union power and environmental groups to block energy projects. 
Regarding the cost of SPS, the following responses were obtained: 30 percent thought SPS would be cheap, 65 percent tolerable, and 3 percent too high. When asked who should develop the SPS, the top ranked answers in order of preference were: federal agencies, combinations of government and industry, private industry, and international units.

When asked who should construct SPS, the top ranked answers in order of preference were: private business, combinations of private business and government agencies, federal agencies, and international units. When asked who should own SPS, the top ranked answers in order of preference were: private business, combinations of private business and government agenciec, federal ayencles and international units. A diversity of ownere in general were suggertod, including the users, the pululic, ntilitico; or lu whomever they are sold or rented to.

Ruspondents were asked to report the arguments pro and con, voiced by their friends in discussions about SPS. About 90 distinguishable arguments were given addressing several topical areas:

- Economic: friends of L-5 members seeing econunic benefits in SPS described it as a feasible energy technology that would provide a cheap, constant, unlimited energy supply, forever. Added benefits were its potiential employment opportunities generated for freo entcrprise, and the impetus it would provide to expand resource development into space. In opposition, SPS was regardcd as ail unsure or infeasihle energy tecluulugy that would be expensive, unreliable and take too long to develop. It was thought to interefere with bctter uplions such as breeder reactors, to continue an undesirable centralization of power, to be too undiversified and too large scale.

- Environmental: SPS was seen as clean, of low impact and safely "off Earth" by its supporters. The opponents thought it wuld have unknown impacts, woul. $\mathrm{n}$ be damaging--ildny cited ilicrowave concerns--or would deplete Earth resources in construction. Radio-TV interference and lack of orbital slots in GEO were also cited.

- Societal: there were friends of L-5 members who saw SPS as sumething to excite the nation and the world, leading off to a New Frontier, and a steppingstone into permanent human habitation of space. On 
the other side, there was condemnation of technology and assertion of the need to work on Earth problems first. A number of people found the idea "too far out" and some didn't know, or care to know, about this option.

- Political: the possiblities of a leadership role for the U.S., freedom from foreign rule and energy self-sufficiency were noted, as was electric power for the developing Third World. Conversely, concerns were expressed about accidental weapons effects, power used for non-peaceful purposes, militarily indefensible structures, and a potential continuation of a centralized power structure in government.

- Technology Advancement: the advancement of knowledge and/or technology was an issue in itself. Stimulation of R\&D funding, of high technology, of an unlimited future was thought to derive from SPS development. Disruption of astronomical work was the lone negative expression about technology.

When asked for an estimation of public acceptance of SPS, 26 percent of the respondents thought it would be easily obtained, 72 percent thought it would be difficult, and $I$ percent thought it would be impossible. When asked about the need for international cooperation on SPS 63 percent welcomed it as an opportunity for peaceful cooperation, 30 percent thought it would be an unwelcome problem, and 5 percent thought it would kill the project. When asked about the possibility that power satellites might form the basis of sophisticated weapons systems: 13 percent thought this would be an advantage, 55 percent thought it would present no problem, and 31 percent considered it to be a major concern.

\section{c. The Government's Conduct of the SPS Program}

Government involvement in SPS research was favored by 89 percent of the respondents. While 80 percent were in favor of L-5 accepting government funds to conduct this study for DOE, 14 percent were undecided, and 5 percent were opposed.

Ninety-five percent of the respondents think funding in SPS research should be increased and only one percent call for a decrease. Forty-three percent think that environmental impacts should be given more emphasis and 
47 percent think societal impacts should be given more emphasis. Although the majority of respondents think the reference system is adequate, several alternative approaches were presented and the respondents were asked to designate those they felt needed more emphasis. The five top ranked options were as follows: use of asteroidal resources (70\%); use of lunar resources (538); mass driver for LEO to GEO cargo transfers (538); solar sails (498); and laser power transmission (48\%). There were many comments concerning the desirability of using extraterrestrial sources of material: for SPS con-. struction.

Ninety-four percent indicated DOE and NASA should be participants in the SPS program, only 26 percent could agree to Department of Defense participation, and only 24 percent could agree to state Department participation. Regarding the Outreach Program, 77 percent said it should be easy for the public to learn all about the SPS program, and 18 percent thought the actlve dialuyue of the outreach program was a good technique.

\section{World Space Center Telephone Interviews}

Six telephone interviews were conducted with associates from Argentina, Finland, Bolivia, Brazil, Liberia, and India. The concerns identified in the interviews are reflected in the following subsections.

a. Ownership and Control of SPS

This was the most important issue to each respondent. They stressed the desirability of an international approach, with the Third World being involved in financing, development, construction and operation of the sPS. In some cases, involvement was seen as essential for Third World approval. They expressed awareness of the influence SPS might have over the world energy supply, indicating that if the U.S. acted alone this could be interpreted as U.S. domination.

Tho question of private versus public ownership and control was not seen as vital. An international consortium facilitating both private and public investment was suggested.

\section{b. International Implications}

Concerns were expressed regarding the ownership of orbital slots and extraterrestrial resources. Four of six respondents saw international ownership as a safeguard against attack on the SPS, as well as a means of allaying fears about the military uses of SPS. Most respondents 
agreed SPS would be more vulnerable than an internal power system, yet they also felt it would be safer because there would be no extended fuel supply routes.

c. SPS Resource Requirements

All respondents indicated that further research would be required in this area. Respondents agreed a decision to build an SPS would depend on the ratio of resource investment problems to benefits.

\section{d. Rectenna Siting Problems}

The responses varied with respect to rectenna siting problems, relative to the land-use situations in each respondent's country. In Bolivia, there is unoccupied land available: In Finland and Argentina rectennas would have to be placed a considerable distance from densely populated areas, requiring expensive transmission.

e. Environmental Effects

Most respndents expressed considerable concern over the danger of possible microwave radiation. The concern expressed was in direct proportion to the extent to which they were familiar with the current interest on the topic. It was agreed that discussion on the safety of microwave transmission will grow internationally as SPS becomes more widely known.

\section{f. Public Attitudes}

Respondents indicated that there is a lack of information about the SPS concept, and therefore there is no formed opinion. All respondents indicated that questions regarding safety, cost, reliability, international politics, and microwave radiation would have to be addressed before public acceptance could be expected. All respondents consider the comparalive coet analysis to be the major deciding factor for acceptance. The importance of public opinion and the degree to which the pulic chould be informed about the SPS concept varied among the respondents, depending upon the tradtional role of public input in decision-making in their respective countries.

\section{Core Group Comments}

There wcre many specific comments received from the core group. Comments on the SPS Reference System suggest there are a number of alternatives that are not being considered; the range of possibilities for space solar 
power are as extensive as those for Earth solar power. The core group suggests that consideration of nonterrestrial materials for SPS construction is important, and in particular, the asteroids are highly accessible objects; a promising new technology is the shaping and stabilization of solar collector surfaces in space by electrostatic charges; and it was emphasized that it is important to be open to innovation and re-evaluation.

Comments regarding international implications were indicative of many international issues which have not been addressed, including soviet opposition to capitalism in orbit, patent law, multilateral arrangements for operational space services, and growth in regional space activities.

Areas of concern were the military implicatiuns of SPS (vulnerability and use as a weapon) and the environmental impact, including land use and terrestrial material resourse allocatiun. Regarding the latter, suggestions include offshore receivers, use of nonterrestrial resources lu circumvent enviromutental impact, rectenna structures doubling as structural supports for greenhouses and an agricultural/rectenna complex, sharing land and energy.

Core group comments on the issue of public acceptance suggest there are a number of factors which will be influential in public acceptance of SPS. The need for cheap, reliable energy (particularly by developing countries); potential spinoffs from space industrialization; grassroots support for sPS from groups such as L-5; public education and public involvement programs are among those addressed by the core group.

4. Membership Response to SPS Questions and Answers

A total of 285 responses regarding "Some questions and Answers About the Satellite Power System" were received. As a whole, the L-5 membership as represented by these respondents, approved of the answers to the questions. Exhibit 4 is a breakdown of responses to each question in terms of three categories: (1) the answer is satisfactory, (2) the anower seems inconmlloto, and (3) the answer is not believed. (See Appendix A for the actual questions and answers.)

The answer which ovokeit the most doubt dealt with whether SPS would eliminate the need for massive coal and oil shale exploitation and attendant disruption of the Earth's surface (Question II-4). Those indicating that they did not believe the answer to this question were 43 , while 62 felt the 


\section{EXHIBIT 4}

FREQUENCY OF RESPONSES TO SPS QUESTIONS AND ANSWERS* BY L-5 SOCIETY MEMBERS

NUMBER OF RESPONSES

\begin{tabular}{|c|c|c|c|c|c|c|}
\hline \multirow{11}{*}{ I. } & \multirow{11}{*}{ ABOUT THE SYSTEM } & \multirow{2}{*}{$\begin{array}{c}\text { QUESTION NUMBER } \\
1\end{array}$} & \multicolumn{2}{|c|}{$\begin{array}{c}\text { SATISFACTORY } \\
\text { ANSWER } \\
\end{array}$} & \multirow{3}{*}{$\begin{array}{c}\begin{array}{c}\text { INCOMPLETE } \\
\text { ANSWER }\end{array} \\
\begin{array}{c}16 \\
36\end{array}\end{array}$} & \multirow{2}{*}{$\begin{array}{c}\text { NOT BELIEVED } \\
\text { ANSWER } \\
1\end{array}$} \\
\hline & & & 264 & 948 & & \\
\hline & & 2 & 239 & 85 & & 5 \\
\hline & & 3 & 214 & 77 & 62 & 3 \\
\hline & & 4 & 246 & 88 & 28 & 5 \\
\hline & & 5 & 239 & 86 & 32 & 6 \\
\hline & & 6 & 212 & 77 & 61 & 3 \\
\hline & & 7 & 230 & 83 & 42 & 4 \\
\hline & & 8 & 224 & 80 & 46 & 9 \\
\hline & & 9 & 192 & 69 & 72 & 15 \\
\hline & & 10 & 214 & 77 & 58 & 6 \\
\hline \multirow[t]{7}{*}{ II. } & ABOUT THE & 1 & 219 & 79 & 52 & 5 \\
\hline & COSPARATIVE ANALYSIS & 2 & 185 & 67 & 87 & 6 \\
\hline & & 3 & 178 & 63 & 98 & 8 \\
\hline & & 4 & 171 & 62 & 62 & 43 \\
\hline & & 5 & 209 & 74 & 59 & 13 \\
\hline & & 6 & 198 & 70 & 62 & 22 \\
\hline & & 7 & 194 & 70 & 82 & 1 \\
\hline \multirow[t]{8}{*}{ III. } & ABOUT THE & 1 & 220 & 79 & 53 & 5 \\
\hline & ENVIRONMENTAL EFFECTS & 2 & 234 & 84 & 37 & 8 \\
\hline & & 3 & 206 & 74 & 69 & 5 \\
\hline & & 4 & 252 & 90 & 23 & 5 \\
\hline & & 5 & 224 & 82 & 45 & 4 \\
\hline & & 6 & 236 & 85 & 41 & 1 \\
\hline & & 7 & 251 & 91 & 21 & 5 \\
\hline & & 8 & 205 & 75 & 65 & 4 \\
\hline \multirow[t]{12}{*}{ IV. } & ABOUT THE & 1 & 243 & 88 & 24 & 9 \\
\hline & SOCIETAL EFFECTS & 2 & 213 & 77 & 45 & 18 \\
\hline & & 3 & 240 & 86 & 28 & 10 \\
\hline & & 4 & 248 & 89 & 27 & 3 \\
\hline & . & 5 & 248 & 89 & 29 & 3 \\
\hline & & 6 & 219 & 80 & 46 & 9 \\
\hline & & 7 & 208 & 75 & G2 & 7 \\
\hline & & 8 & 238 & 86 & 35 & 3 \\
\hline & & 9 & 205 & 75 & 61 & 9 \\
\hline & & 10 & 253 & 92 & 19 & 5 \\
\hline & & 11 & 229 & 83 & 37 & 9 \\
\hline & & 12 & 244 & 87 & 23 & 4 \\
\hline \multirow[t]{7}{*}{ v. } & ABOUT THE & 1 & 258 & 94 & 10 & 6 \\
\hline & DOE PHWOKRAM & 2 & 246 & 91 & 17 & 9 \\
\hline & & 3 & 247 & 91 & 24 & 2 \\
\hline & & 4 & 220 & 80 & 43 & 12 \\
\hline & & 5 & 220 & 79 & 46 & 11 \\
\hline & & 6 & 233 & 85 & 30 & 12 \\
\hline & & 7 & 220 & 80 & 44 & 12 \\
\hline
\end{tabular}

- see Apperidix A for actual questions and answers. 
answer was incomplete and 171 considered the answer satisfactory. Over 40 people specifically added comments that DOE's failure to include extraterrestrial resources in the reference system prevents the plan from avoiding terrestrial disruption.

Three answers were singled out for incompleteness, receiving 82 or more votes for either not dealing with the question directly or for leaving out salient considerations: Question II-3 concerning environmental and settlement pattern disturbance due to SPS rectenna siting; II-2 concerning the SPS cost; and II-7 dealing with the impact of SPS on labor.

The answers with which fewest people had doubts were I-1, about the de-orbit dangers from SPS; $\mathrm{V}-1$ on why DOE is even involved in the SPS program evaluation; and IV-10 involving power disruptions.

\section{EUMMARY}

Since the L-5 Society's purpose is to promote ventures in space, a favorable attitude toward most extraterrestrial enterprises is to be expected. The 83 percent favorable response regarding the potential of the SPS concept as a major energy source by the end of the century reflects the Society's optimism and also the image of SPS as a "driver" for space exploitation.

On the basis of this outreach experiment, responses from L-5 participants have been summarized by the L-5 staff in the following message to DOE:

- Solar power satellites look like a prime option for future energy needs.

- Private enterprise will be interested in SPS.

- The U.S. government should have a supportive and regulatory role in the project.

- The Reference System needs major revisions.

- Environmental and social impacts must be calculated into the cost/ benefit analysis for SPS development and deployment.

- If SPS would increase centralization of power, it will have to provide clean, cheap power.

- The military implications of SPS are serious. A mecharism is needed to assure nonaggressive use.

- National rivalries and international bureaucratization could become a major hindrance to SPS development. 
- Nations will cooperate in the development of SPS if they share its use and benefits, but not if the benefits are restricted to one nation or group of nations.

- SPS can come on line sooner than the 25 years presumed in the Reference System concept.

- The extraterrestrial resource option for building SPS should be pursued.

- SPS is in danger of being over-studied.

- Night sky brightness and interference will cause difficulty with astronomers and environmental groups. 
V. PARTICIPATION OF THE FORUM FOR THE ADVANCEMENT OF STUDENTS IN, SCIENCE AND TECHNOLOGY

A. METHOD

The method of outreach used by FASST consisted of the following activities:

- An SPS Briefing Packet was prepared including:

- Nineteen summaries of SPS reports, written by seventeen students from eleven universities. The FASST staff prepared two summaries when students were unable to meet printing schedules. The FASST staff edited and prepared these summaries in the FASST BRIEFING format.

- A cover letter explaining the program.

- A response form requesting demographic information, sources of information which familiarized the respondent with SPS, ratings of the BRIEFINGS format, and comments or questions on the SPS concept.

- Briefing packets were mailed to 3,000 individuals on the FASST mailing list. Approximately 1,500 were students, and the other 1,500 inclided faculty members and individuals not affiliated with a university, but interested in the programs of the Forum. The faculty lists included 1,100 professors of courses related to science/society courses.

- All data from the returned response forms, with the exception of comments or questions on the SPS concept, were tallied and cross tabulated according to academic standing. Comments or questions on the SPS concept were categorized according to topical areas.

- The telelecture, a non-print communication method, was investigated as a means to further disseminate information to the college community. During the CDEP this method was researched, a trial demonstration was conducted, and evaluations by participating students were obtained.

- The document entitled "Some Questions and Answers About the Satellite Power System" was sent by DOE to a list of FASSr outreach respondees. (The questions and answers from this document are presented in Appendix A.) In antioipation of this mailing, FASST sent: a letter informing the respondees of the forthcoming document and requesting their feedback on it.

B. RESULTS

A total of 306 response forms were received by FASST, for a $9.5 \%$ return rate. The responses came from students, faculty members, and professionals at 153 academic institutions in 40 states, the District of Columbia, and five 
foreign countries. Overall, the participants ranged in age from 14 to 71 , with an average age of 26 . The participants represented 40 academic disciplines. Male participants numbered 243 (80\%), while females numbered 63 (20\%). Respondents' academic standing was as follows:

- High School Students 118

- High School Faculty 3\%

- Junior College Students $2 \%$

- Junior College Faculty $1 \%$

- College students $57 \%$

- College Faculty $18 \%$

- Non-Academic Professionals 9\%

Of the 306 participants, 84 percent (254) wrote comments and questions on the response form. Those who wrote a few lines up to a half page represented 46 percent (141), while 40 percent (115) offered comments from a half page to several type-written pages. Analysis of these comments was broken down into topical areas. Conclusions were drawn from these comments, each supported by a series of quotations from the written comments.

1. About the Briefings

Sixty-three percent (192) of the participants indicated that the FASST BRIEFINGS were a primary source of information on the sPS concept. Information from NASA ranked second with 58 of the participants, while professional societies were mentioned as the third highest source of information. Other sources included newspapers, the classroom, DOE, magazines, TV, radio, books and hearings. Ratings of the FASST BRIEFINGS as a means to inform and involve the campus community were as follows:

$\begin{array}{llr}\text { as a means to inform } & \text { excellent } & 54 \% \\ \text { the rampus community } & \text { good } & 33 \% \\ & \text { fair } & 10 \% \\ & \text { poor } & 3 \% \\ \text { as a means to involve } & \text { excellent } & 30 \% \\ \text { the campus community } & \text { good } & 43 \% \\ & \text { fair } & 22 \% \\ & \text { poor } & 5 \%\end{array}$

Those participants who gave the BRIEFINGS favorable ratings appreciated the opportunity to participate in the SPS discussion and felt the packet was informative and thorough. 
Conclusions drawn by the FASST staff from the written comments about the BRIEFINGS include the following:

- While the BRIEFINGS helped many to shape their opinions about the SPS, the amount of information presented showed others that the issues are not necessarily black and white. Several respondents stated that they were still unsure of how they felt about the SPS and would need more time to think things through.

- The BRIEFINGS provided an opportunity for input into the evaluation and succeeded in illustrating the complexity of SPS.

- Suggestions for improvement focused on reducing the extensive amount of materials that the participants were asked to read, and providing an outline and table of contents.

In addition, the results of the outreach have demonstrated that the BRIEFINGS had value as a tool in both formal and informal educational settings. Because research on the SPS concept is so recent, the opportunities to disseminate this information to the academic community have been limited. The FASST BRIEFING Packet, therefore, served as a basic "textbook" on this proposed energy technology.

- A total of 45 classes applied the BRIEFINGS to the formal educational process. For example, at. Mansfield State College (Pa.) a physics professor designed an entire course, "Solar Satellite Power System: An Alternative Energy Source", around the FASST BRIEFINGS.

- An Energy Seminar Group was formed at the Environmental Studies Center of the State University of New York at Buffalo. The twelve graduate students relied on the BRIEFINGS for background material and compiled a final report as a class project.

- A high school physice teacher in Jackson, Tennessee assigned individual BRIEFINGS to his students, requested a paper on the topic, and discussed the overall concept as a unit of instruction.

- Two medical students, a nursing student, a social worker, and a professor of pathology at the University of Texas-San Antonio formed a seminar group to discuss SPS. As part of a course on the Social and Moral values in the Health Sciences, the BRIEFING Packet was used to prepare a discussion agenda for the seminar. Suggestions were forwarded to the Forum as part of the class assignment.

- A professor at George Washington University distributed 40 packets to students of a course on Science, Technology, and Politics. The material provided the students with background information to prepare papers on selected SPS policy questions. 
Written comments from those engaged in more informal educational situations suggest their motivation to participate developed from self-realization goals. Regardless of their personal opinion of the SPS, they recognized the importance of promoting public participation in technological discussions. Much of the independent research that began as an informal activity evolved into class projects.

\section{Reference System}

The issues of vulnerability and control of the sPS were often raised. There was concern as to how well the SPS would withstand either planned attacks from an enemy, or natural disasters. Several questions were raised related to necessary manpower and maintenance requirements and to the life-support for the space workers. These points were not clear or inadequately covered in the BRIEFINGS. Many felt the reference system lacked credibility because lunar materials for construction of the satellites were not included. Other questions and comments on the reference system focused on the costs, as well as on alternatives other than using Iunar materials.

3. Comparative Energy Analysis

Although the BRIEFING Packet's cover letter mentioned that a comparative assessment study was in progress, numerous participants seemed to think that this was an area that was ignored. An early BRIEFING paper on the comparative assessment might have answered questions such as how space-based and terrestrial solar systems compare. There was also some concern that SPS funding would detract from fusion research and efforts to promote conservation. The general recommendation from the participants seemed to be that SPS should be part of an overall research strategy.

\section{Environmental Effects}

The potential problems associated with microwaves were the environmental effects mentioned by the participants. Those who were concerned about the potential effects of microwave exposure saw this problem as a major 'show-stopper' to the entire project. When comments were offered regarding a microwave versus laser system, the latter achieved a higher level of acceptance. Impacts on the atmosphere were also a frequently reported environmental concern. 


\section{Social Effects}

The issue of centralization/decentralization generated considerable comment from the participants---especially from those opposed to sPS construction. The negative implication was that SPS will require a strong centralized system similar to 'big oil' companies and 'utility monopolies'. An international structure for the SPS was endorsed by many. Although the degree of difficulty involved in an international organization was recognized by many, they nonetheless felt that it was vital if SPS were to succeed.

Closely linked to the discussion of international cooperation were comments and questions on the military implications of the SPS. Most participants believed that the SPS would require a defense against possible attack, but that its oftensive capabilities should not be emphasized.

A final thought on the societal implications was mentioned by more than a few students, even though it had not been discussed in the BRIEFINGS:

"Whc will insure that 60 satellites if each is the size of Manhattan Isli id?"

\section{Tise Outreach Effort}

Regardless of how the participants felt about the concept of the SPS, there was almost unanimous support for some form of public discussion on the related issues. A belief that a vigorous public awareness program about the SPS should begin immediately was evident from the responses. Although DOE's role in the SPS evaluation was not of concern to most of the participants, the Department's involvement in such a project did not escape without some criticism.

7. SFS Concept: Support and Opposition

The participant's specific opinion on the concept of the SPS was not solicited. Based on an analysis of the written comments, however, 50 percent (153) had no definite opinion on the SPS; 26 percent (80) were unsure of their opinion or thought that further studies should be completed before they could form an opinion; 14 percent (43) supported the SPS concept; and 10 percent (30) did not support the concept.

Participants who felt that it was too early to give a specitic opinion often suggested further studies or offered conditional endorsements for the concept. For example:

"I will support the SPS concept if---it can be protected; raw materials will primarily be taken from the Moon; and funding does not come from other space exploration projects." High school senior interested in aerospace engineering career, Rutherford, New Jersey. 
Those who support the SPS concept feel the program should proceed immediately and many who favor the development of the SPS see it as a means to achieve or contribute to other ends. For example:

"Although more complex than I thought, I believe that we ought to develop the needed technology for the SPS. It would seem that the spin-offs can be more of a benefit than the original project." High school senior interested in aerospace engineering career, Monmouth, Illinois.

Those participants who opposed the construction of SPS cited numerous problems related to the environment, military applications, and economic considerations. For example:

"In general, our group has had. a strong negative reaction toward this proposal for a variety of reasons, but mainly because its total dependence on a risky, highly technological, massive, complex development and an organizational structure of unprecedent dimensions... The concept is inherently flawed in that it derives its energy from a single, complex, capital intensive source." Graduate seminar of 12 students, Environmental Studies Center, State University of New York at Buffalo.

While the BRIEFINGS helped many of the participants shape their opinions about the SPS, the vast amount of information showed others that the issues were not necessarily black and white. Several participants stated that they were still unsure of how they felt about the SPS and would need more time to think about the issues. The following comment, from a sophomore engineering major at McKeesport Campus of Pennsylvania State University, typified these individuals:

"It is hard for me to summarize how I think and feel about the SPS. I started reading them (the BRIEFINGS) with the attitude, 'of course they should be built,' but as I read about the amount of required land, the long distances that power would have to be transported, the possible dangers to life, and most importantly, the myriad of unanswered questions concerning the basic parameters of the project, I wondered if it might not be more efficient to manufacture solar cells in space with which to cover roofs of houses. Factors which I had not considered before, such as the military implications, have me even more skeptical than when I started the BRIEFINGS."

8. Further Involvement

An unexpected result of the Public Outreach Experiment included requests by students to become directly involved in SPS research, now. Numerous participants indicated their intention to pursue aerospace careers, in general and related to SPS in particular. They wanted to know how they could begin to plan their academic careers around SPS involvement and/or how to become participants in SPS research. 


\section{The Telelecture Method}

The telelecture method involves a presentation of information through a combination of slides and the telephone. Arrangements are made to have a group meet in a room equipped with a telephone linked into a speaker or conferencecall amplifier. At the designated time, a speaker--generally in a different city--calls the group to present a lecture, accompanied with slides which have been sent to the group in advance.

A presentation of the telelecture method took place during the second semester of the 1979-80 academic year at Mansfield state College (Pa.). In addition to those who enrolled in the course, other students were invited to at tend the program. Therefore, the audience included both students with and without knowledge of the SPS concept. FASST arranged for a presentation to be given by a member of the NASA staff in Washington, D.C.

A review of student evaluations of the program suggests that the telelecture experiment was successful and an effective method for discussing the SPS concept with the campus community. The lecture helped to clarify information that had been presented in the FASST BRIEFINGS, and presented information on new studies. The students reported they felt a part of the process and were impressed with the opportunity to discuss the topic with a NASA official.

10. Response to SPS Questions and Answers

Due to some administrative problems, the DOE mailing of the SPS Question/Answer document to FASST respondees was delayed nearly three months following the FASST letter of announcement and request for feedback. This delay, coupled with the fact that the academic year was over, are considered to be the major reasons for a zero response to the request for feedback on this document. C. SUMMARY

According to FASST, the SPS Public Outreach Experiment has demonstrated that the Public (including students) will contribute to terhnologisal discussions when given access to the process. Based on several respondent comments, FASST states it is important for the public to feel part of the decision-making process. Succinctly stated by a student respondent:

"I cannot emphasize enough the important nature of the FASST effort in bringing these issues to the attention of the public. The most important question about the SPS concept is not whether it will or will not work, it is whether the public will have a chance to examine the issues and decide collectively whether the large investment it entails should be undertaken. There will always be uncertainty regarding the final outcome of the decision; the best we or the DOE or the other government agencies can do is to insure maximum input from the people who will pay for the entire system and who will be affected by the system--which, in this case, is the entire country." Health policy graduate student, Massachusetts Institute of Technology. 
Based on the experience in the SPS Public Outreach, FASST offers several recommendations for future participation efforts:

- General Recommendations

- Provide longer lead time to administer outreach programs

- Improve the contract procurement process for contractors

- Increase contact and dialogue between contractors and the SPS Project Division

- Develop an evaluation mechanism to determine what constitutes effective public participation

- Continue research on public participation methods.

- Recommendations on the Briefing Packet

- Offer a more concise version of the BRIEFINGS

- Include a glossary and list of sources for additional information

- Market individual BRIEFINGS

- Develop a common response form for all organizations involved in public participation projects.

- Recommendations for Classroom Activities

- Inform faculty members about participation projects at least three months prior to sending out information packets

- Distribute a progress report to the project participants.

- Recommendations for Telelectures

- Develop panel presentations for telelectures

- Concentrate telelectures on schools out of the main stream

- Require contractors to participate in telelecture programs

- Publish a "How To" booklet on the telelecture process. 


\section{APPENDIX A}

SOME QUESTIONS AND ANSWERS ABOUT THE SATELLITE POWER SYSTEM

I.

I.1 Will an orbiting satellite the size of SPS be stable at GEO or will it de-orbit like the Skylab and be a potential danger to the people on the ground?

The atmospheric density at geostationary orbit (GEO) is so low that synchronous satellites are generally considered to have an indefinite lifetime. However, the SPS would have a much smaller mass to area ratio thán any previous satellite at this altitude and thus would be more subject to atmospheric drag. An investigation of orbital decay of the SPS components $1 /$ found that decay of the satellite over its 30-year lifetime could be expected to lie between 0.25 and 2500 meters, i.e., less than one part in 10,000 in the worst case. Other components at geostationary orbit (construction bases, etc.) would be influenced even less since they have higher mass to area ratios. There are perturbations from other causes such as solar radiation pressure, lunar/solar gravity gradients, and the equaturial ellipicity of the Earth. These arp. snmewhat larger than the atmospheric drag effect (although still small) and will be accomodated with planned station-keeping.

A more significant problem is presented by the components in low Earth orbit such as the stag1ng base and the electric orbital transfer vehicle during loading and servicing opcrations. Both of these components would experience decay of such llugullude that cosentially aontinuous nrhit maintenance will be necessary. Loss of orbit maintenance capability would result in irreversible decay in a matter of weeks. Thus, all the subsystems involved (guidance, propulsion, stabilization, power) will be highly redundant and rapidly repairable so as to make uncontrolled orbit decay nearly impossible. It will also be necessary to keep sufficient reserve propellent onboard to continue operations in case of launch failure of the resupply vehicles.

Launch vehicle range safety will require that launch failures do not result in land impact. Since this corresponds to current practice, no unique requirements are foreseen for SPS launch vehicles simply because of their size.

In short, a preliminary investigation of orbital decay of SPS components from launch to geostationary orbit indicates that it is either insignficant or manageable with current procedures. Additional investigation will be conducted, particularly. ful lauich and the compenonts in $1 \mathrm{nw}$ Earth orbit as these become better defined.

I.2 How vulnerable is the SPS to partial or totdl desldution, aspccially the space segment? For example, do meteor showers pose any threat to the space segment?

The principle area of concern ahout SPS satellite vulnerability has to do with overt military action. It is highly unlikely that terrorism could pose a direct threat to the satellite on orbit because of its inaccessibility.

The threat of overt military action against the space segment -- bull satellite and ground-based cnntrnl system -- is real, although ils execution would clearly constitute an act of war. Satellites with hunter-killer capability up to synchronuus allitudes, if not opcrationally avallable today, could be in the near future. Although various hardening measures and self-defense provisions can be implemented, absolute protection of the satellite cannot be assured.

The large scale of the satellite tends to make it somewhat less vulnerable than would be the case otherwise. The large size means that redundant subsystems can readily be provided, and indeed may be mandatory for reliablitty reasons. The high powe l level meang that many parallelm ed (redundant) energy circuits can be used in the design. The large scale also means that substantial weapons are needed to do more than partially disable the satellite. It may turn out that because of this large size, the high orbital altitude and the fact of being in a space environment, nuclear weapons would be the only likely ones with a good probability of achieving assured destruction.

Sabotage of the satellite is a rather unlikely threat. Although preparation of the components for the satellite gives ample opportunity for saboteurs because of the great quantities involved, 
the nature of the satellite is such that at later stages in its construction these opportunities become more restricted. Parts and materials are subjected to extensive inspection and testing because of their end use; this should be quite effective against sabotage. Also, the final assembly is done on orbit by. operators who are necessarily carefully screened and selected.

The vulnerability of the rectenna to overt military action, terrorist attack or sabotage is not greatly different from that of other large utilities. Rectenna operation, however, is not dependent on a critical fuel supply line such as coal or oil, which can be rather easily interdicted $2 /$, rendering the rectenna to that extent less vulnerable than other large power plants. Concealment, hardening, protective sheltering and other measures can provide limited protection. The rectenna will be part of an interconnected utility grid, so that the loss of any one station (or satellite) is not necessarily critical.

The large size and inherent redundancy of the satellite would also protect it from all but the most unlikely meteor showers or individual hits.3/ More significant factors in Earth orbit are heat transfer, vacuum, particulate and ultraviolet radiation and interactions with the plasma. Assessment of these environmental effects is hampered by lack of experience with large spacecraft but is proceeding at a theoretical level. 1 /

I.3 Is there a way that rivals, unauthorized personnel, etc., can gain control of the SPS?

A fully operational SPS for the United States might consist of 60 satellites, a like number of rectennas, a transportation complex and a highly redundant command and communications subsystem. There is no credible way that this system could be commandeered short of war. The power beam from an individual satellite to its designated rectenna is enabled and controlled by a pilot beam. The pilot beam (which may be redundant for purposes of reliability) provides the information to the satellite to focus the power beam and to keep it precisely pointed at the rectenna. If for any reason the transmitting antenna is pointed away from the rectenna, the power beam defocuses and becomes indistinguishable from.the background nolse. The pilot beam is coded to operate only with its designated satellite and to preclude its duplication from an unauthorized source.

I.4 What is the basis for the claim that the satellite will have a 30-year lifetime?

This is not a claim; rather a 30- year lifetime was selected as a design guideline for operation planning and costing exercises. The ever-lengthening lives of current unmanned satellites, however, together with the rather benign conditions in geostationary orbit (no gravity, no weather, very little wear, etc.) suggest that 30 years, with maintenance, may not be an unreasonable goal. Refurbishment is also part of the program planning for SPS and could extend satellite lifetime considerably beyond 30 years.

I.5 Have maintenance requirements been considered in the analysis of the reference system concept? How could maintenance be performed?

Maintenance requirements have been considered in the reference system analysis as part of the rellability and lifetime analysis. Costs and manpower have been estimated; including spare parts, transportation and level of effort. Much of the maintenance associated with the rectenna would be conventional in nature, and include maintaining roads, rectenna panels and supports, the pnwer collertion and tranomiooion systelus dul cuntrul center. Most of the work would entail general equipment maintenance. Estimates of labor for scheduled and unscheduled maintenance and repair of the rectenna and electric power collection system have been estimated at 64 employees $\underline{5} /$ per rectenna.

To determine maintenance requirements for the satellite, elghteen SPS components were selected for detailed analysis. The components were selected for one of three reasons: 1) the component was representative of a class of components, 2) failure of the component results in significant power loss or 3 ) the component is highly stressed and could have a high failure rate. The numbei ul personnel required tor satellite mainterance would be a function of the amount of direct versus remote monitoring. It is currently estimated that the 60 - satellite system would be maintained by about 975 workers, $6 /$ probably stationed at the GEO construction base and ferried back and forth to the satellites, as required. $\underline{7}$ 
The mission control center (MCC) would have developed a detailed listing of faulty components and spare parts would be available from the warehouse or would accompany the maintenance crew. Upon arrival, a flyover of the satellites would be made to detect non-annunclated fallures. The maintenance vehicle would be loaded and defective components removed and replaced. The defective components would be returned for test and refurbishment. Each satellite would be refurbished in $3 \frac{1}{2}$ days with double shift operations. Most of the work would be performed by teleoperated machine and monitored by space workers. This high level of maintenance would enhance confidence in the projected 30 year lifetime.

I.6 Will new life support systems be required for space construction crews or is present technology sufficient?

Life support systems encompass (1) the control and revitalization of a habitable atmosphere, (2) provision of food and water, (3) solid and liquid waste management, (4) space suits and emergency equipment for personnel safety and rescue, (5) personal hygiene, and (6) instrumentation and data management equipment. While all these subsystems currently exist, additional R\&D on each of them will be required for an operational SPS.

Basically, life support systems using techniques of regeneration will be required because the rnst of providing expendable items for the life support function is prohibitively expensive. Major advances required for the SPS are likely to 1nclude oxygen recovery and closure uf tlie water/waste management system. A significant amount of research and development has been conducted on regeneration life support processes and some tests have been performed. A continuing research program covering all the areas has been defined 8 / which could be readily adapted and extended to satisfy specific SPS requirements as these become better known.

I. 7 What are the manpower and training requirements to bulld the satellite?

The number of SPS personnel in orbit would vary with the stage of deployment but would be on the order of 1000 at any given time.9/ For example, after construction of about one-third of the 60 -satellite system, one scenario would have 827 people manning the GEO base. This crew would consist of SPS construction personne1 (417), satellite maintenance (383) and transportation systems maintenance (27). The SPS construction crew would be composed of four types of personnel:

1. Base Management (17)

2. SPS construction (262)

3. Bäse support and uperaliuns (120)

4. Operations safety (18)

The crew would include men and women, and would be selected for sound physiological and psychulogical conditions. Well educated and highlÿ morlvared 1ndlvlduals wiuld be selectcd.10/ $\Lambda 1-$ though labor-spectfic requirements have not been identified, most of the traditional occupations would be represented: electricians, plumbers, cooks, accountants, englneers, etc. Space worker training would include specific job related training as well as instruction on maintaining health, safety and well being in the space environment. A program to analyze manpower and training program requirements has been identified. This study will be undertaken in the next study phase if a decision to proceed is made.

Much of the manpower needed to develop the SPS (including the satellites) would be those associated with traditional terrestrial projects - mining, materials extraction and processing, component manufacture, etc. In addition, construction of the satellite element would require coordinated effort at GEO and LEO staging bases, as well as support from Earth bases. The space worker estimates assume 10 support people on the ground per space wurker.

I. 8 How should today's students be preparing themselves in terms ur Lidining and education bo ac to have a greater opportunity for more direct involvement in any future spS undertaking?

If one assumes that SPS will become an operational syslem early in the next century today's students would have careers roughly paralleling the research, development, demonstration, deployment and initial operation of the SPS. Since this program involves so many disciplines scarcely anyone would be precluded from participation because of a specific career cholce. 
However, the next ten to twenty years will of necessity emphasize research and development. This suggests that engineers will have an edge over welders, system planners will be more sought after than stock clerks, and biophysicists will more likely find sPS-related employment than nurses.

The skills mix required to accomplish SPS goals will change as the program unfolds and 30 to 40 years from now there is likely to be a strong demand for registered nurses, stock clerks and welders while many experienced SPS engineers, systems planners and biophysicists will be moving on to new projects requiring their skills.

The SPS program will require individuals at all levels of the management/organizational structure with the ability to:

- Design the SPS, including terrestrial, space and transportation elements, and components.

- Deploy the SPS; fabricate elements and construct them in space and on Earth.

- Interface with institutions, including international and local bodies, financial organizations, land owners, insurance agencies, utilities, users, etc.

- Evaluate SPS environmental and societal impacts and suggest appropriate responses.

- Operate and maintain both the space and ground components of the SPS.

While the space segment of the system may have the highest profile, visually as well as job related, the majority of jobs will continue to be in traditional fields.

I.9 Which is the cheaper reference system design - Rockwell's or Boeing's?

Within the range of present uncertainties, total system cost is the same for both designs. While the most recent estimates show the Boeing satellite to be cheaper, it is also heavier and the transportation cost is therefore higher. Both designs assume cost improvements of a factor of 10 or more in several elements (space transportation, solar arrays, etc.) in order to make the system economically viable. Thus, their "estimates" are really more in the nature of goals. Comparable sets of figures derived in early 1979 are shown in the following table.11/

$\begin{array}{lrr} & \begin{array}{c}\text { Boeing } \\ \text { (Millions of }\end{array} & \begin{array}{c}\text { Rockwell } \\ \text { Satellite }\end{array} \\ \text { Ground Receiving Station } & 3,917 & 5,328 \\ \text { Space Transportation } & 3,242 & 3,600 \\ \text { Space Construction \& Support } & 1,248 & 1,872 \\ \text { Mass Contingency } & 1,130 & 1,152 \\ \text { Management and Integration } & \$ \frac{421}{2,421} & \$ 1 \frac{576}{4,400}\end{array}$

The SPS PD is currently auditing these cost estimates. Preliminary indications are that SPS costs may be in the neighborhood of $\$ 3600 /$ kilowatt, compared to the approximately $\$ 2400 / \mathrm{kW}$ estimated by the contractors. The audit is continuing, however, and will be fully reported later in the year.

The problems inherent in deriving SPS cost estimates have been treated extensively by Hazelrigg who indicates that "it is not, by any means available today, possible to predict the cost of an SPS to be built in the year 2000 , to better than about an order of magnitude."12/

I.10 Is the DOE considering alternative reference system concepts? If so, how much monely is heing allorater for thooc atudies leldllve to the current status reference design?

The SPS Project Division is evaluating alternative concepts and subsystems at the present time. For example, a laser power transmission system has been identified as an alternative ton the 
microwave power transmission system. Solid state technologies arc being investigated as alternatives to the present spacecraft transmitting antenna design. During FY79, about $15 \% 13 /$ of the NASA budget for SPS studies went into these areas. Should there be a decision to proceed with further SPS investigations after the end of the current program, the SPS PD will continue to evaluate emerging technologies to determine their applirability.

The present reference system is a concept being used as a "strawman" for the environmental, societal and comparative assessments. It is not an optimum concept, detalled design or recommended configuration.14/ The SPS PD has considered many other systems in the past and continues to study others as their technology develops. A partial list of alternatives considered to date would include:

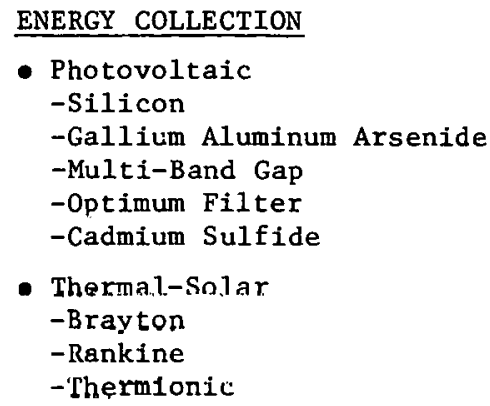

II. ABOUT THE COMPARATIVE ANALYSIS

\author{
ENERGY TRANSMISSION \\ - Microwave \\ -Power Amplification \\ - Amplitrons \\ - Magnetrons \\ . Klystrons \\ . Sulid State \\ -Phase Control \\ - Retrodirertive \\ . Ground
}

- Iraser

II.1 Will there be a comparative analysis of the SPS with alternative energy technologies?

A comparative assessment of the SPS is part of the SPS Concept Development and Evaluation Program. The analysis sequence for the comparative assessment consists of six main steps:

- Comparative Issues Selection

- Energy Alternatives Selection

- Energy System Characteristics

- Side-by-Side Analysis of Energy Systems

- Alternative Futures Analysis

- Integration/Aggregation Technique Development

The first four ctops have heen taken tn a pieliminary oocessment $15 /$ and a methodology has beuit ratahlished for accomplishing al1 six steps.16/ The final assessmene wlll cuinpare tho sBS and seven alternative energy technologies in the dleds of iost and porformanrf, pnvironmental effects, human health and safety, resource utilization, and economic, societal and international issues. The alternative energy technologies to be characterized include light water reactors, liquid metal fast breeder reactors, advanced coal-fired steam plants, coal gasification/combined cycle plants, terrestrial central station photovoltaics, and fusion reactors. In addition, an appropriat.e decentralized energy technology alternative will be characterized and evaluated. The SPS Comparative Assessment is scheduled ful tü̈pletiun in November $1.98 n$.

II.2 Has a net energy andiysls beeil lone whioh sompares the SPS with alternative energy technologies?

Energy analyses of the SPS have been compared by the Johnson Space Center, $17 /$ the Marshall Space Flight Center, 18/ the Energy Research and Development Adwluistration Tack Groun nn Satellite Power Statione, 19/,20/ Llie Jet Propuleion Labnratory, 21/ the SPS Project Division, 22/ and the University of Illinois Center for Advanced Computation. $23 /, 24 /$ SPS energy latios have been fouml that range from marginally favorable to very favorable in relation to other energy technologies.

Considerable controversy exists regarding energy analysis methodolugies and thcir results. A particular point in dispute is whether or not fuel should be included in the system boundaries. Perhaps the must common measure used in energy analysis is the net energy ratio defined as 
For many purposes it is desirable to exclude fuel from the denominator of this expression. Doing so for SPS and other solar energy systems that use no primary, non-renewable energy as fuel excludes their most desirable feature. Solar photovoltaic systems also tend to have lower energy ratios than fossil or nuclear systems because of the current high energy intensities involved in the production of solar cells. However, when fuel is included in the calculation the energy ratios of nuclear and fossil systems drop to a fraction of the lowest value found for sPS in the studies cited above.

As a subtask of the Comparative Assessment, a net energy analysis is being conducted which will attempt to resolve some of the controversy inherent in this topic by carefully comparing the two solar cell options of the SPS (silicon and gallium-aluminum-arsenide) with coal, nuclear and terrestrial solar electric energy systems. The final comparative assessment report is scheduled for completion in November 1980 .

II.3 How much disruption of human settlement patterns and wildlands will the SPS rectenna system create in comparison to coal and oil shale fuel cycles?

A detailed study is in progress at Rice University to find areas in the United States that satisfy specified criteria such as minimum population density, non-agricultural use, water availability, non-interference with flyways of migratory fowl, etc.25/ The study will reveal areas that are potentially suitable for rectenna siting, or as sites for other power plants, as a function of input criteria. Determination of ultimate suitability would require site-specific analyses for competing scenarios which would include estimates of disruption to human settlement patterns and wildlands.

Three basic siting scenarios are possible:

- Remote location with transmission to demand

- Remote location with demand moved to supply. This was done with western hydropower

- Design SPS for joint land use in or around demand centers (over a water reservoir or special farming area)

How human settlement patterns change depends on the location of SPS rectenna sites in relation to year 2000-2030 population and industry centers and each scenario would create different effects.

The SPS Comparative Assessment is examining the land requirements of SPS and alternative technologies and will provide information to more fully answer this question. The final comparative assessment report is due in November 1980 .

II.4 Would the SPS be functional soon enough to obviate massive coal and oil shale exploitation or do the timeframes for utilization of these alternative technologies and attendant environmental impacts overlap?

U.S. energy consumption is expected to increase at a small, but significant rate in the midterm (1985-1995). A recent DOE Energy Information Administration study $26 /$ projected energy consumption to increase at annual rates between $2.8 \%$ and $1.6 \%$ for the midterm period. Although this is lower than historic trends (the annual rate of increase for the ' $62-' 72$ period was $3.8 \%$ ), by 1995 it will result in annual energy consumption, respectively, $165 \%$ or $135 \%$ greater than 1977 consumption of 80 quadrillion Btu. Continued reliance on fossil fuels will accompany this increase at least through the short and mid terms. The level of development and utilization of coal and other fossil fuel sources during the next 20 to 30 years will depend on the actual increase in demand for electricity and the degree to which conservation options are utilized by society. The SPS holds promise unly for the long term, and could not make a significant contribution to electric supply for the next 25 years. 
II.5 Would a breakthrough on fusion obviate the need for SPS? What forms and amounts of energy would fusion energy replace that would reduce the need for SPS?

Fusion is a baseload central station electrical option, and therefore a companion technology to SPS. A competitive scenario exists only if both options are available at the same time, at similar costs, and under conditions for which energy supply shortfalls can be satisfied without having to resort to a mix of both options. If both are technically and environmentally acceptable, then other criteria would determine if SPS would be part of the energy portfolio along with fusion. A breakthrough in fusion would call for a reevaluation of all immediate post-2000 electric technologies.

II.6 Wouldn't a breakthrough in terrestrial solar technologies reduce or eliminate the need for sPS? In particular, wouldn't advances in photovoltaics benefit terrestrial applications to the point where the SPS would be obsolete or comparatively uneconomical?

If we compare baseload terrestrial photovoltaics to SPS, then a breakthrough in solar cell Lechnology would bring down the cost of both systems. Most likely the decrease would favor terrestrial photovoltaics, but storage cost must also be reduced to increase the competitive position of baseload applications of terrestrial photovoltaics. Therefore, a breakthrough in photovoltaic technology and/or storage techuulogy would require careful analysis against supply/demand, and economic, societal and environmental issues at that time.

II.7 What impact will development of the SPS have on the labor market compared to alternate energy endeavors - Will it be labor-intensive or capital-intensive?

A quantitative answer ls not avallable at thio timo. Hnwever, ic 1 s kiluwn that EPS, as we11 as terrestrial photovoltaics and other distributed solar technologies, will most likely utilize mass production facilities, most of which will be automated. Although the space construction portion of the satellite and operations will be highly automated, support service, rectenna construction, and maintenance labor requirements will he high and comparable to coal, nuclear, and central station solar technologies. The distributed technologies will differ in that they will utilize more local labor to assemble (roof-top modification, etc.) install, operate and maintain these technologies than does SPS or conventional technologies. The SPS Comparative Assessment, scheduled for completion in November 1980, will more fully address this question.

III. ABOUT THE ENVIRONMENTAL EFFECTS

III.1 A prominent concern is the microwave bio-effects of the SPS power transmission system. What happens to people and ecosystems outside the rectenna site should control of beam directionality be lost?

Microwave power densities have been calculated for the case uf lotal foilure of the phase control system.27/ If the uplink pilot beam Lfausuitter at tho restenna is shut off, for example, the sub-arrays on the sacell1ie dultima will no longer he phased together and the total beam will be defocused. The peak intensity of the beam at ground level drops to $0.003 \mathrm{~mW} / \mathrm{cm}^{2}$ and the Leam width greatly increases. The power density of a defocused beam is less than the ambient level for television transmissions within the average city and is significantly less than the U.S. and the U.S.S.R. guidelines (10 and $0.01 \mathrm{~mW} / \mathrm{cm}^{2}$ respectively). Under normal operations, the general population and off-site ecosystems would be exposed to power densities ranging from 100 to 100,000 times bel nw the U.S. standard limit (up to 100 times below the U.S.S.R. standard limit). Preliminary investigations in several priority areas (e.g., Lumumulogy and homatology; mutagenesis, carcinogenesis, reproductiul, teratology and growth) reveal no expectation of impairment of the general population or animal and avian members of ecosystems outside the rectenna site.28/ Further investigations are planned in these and other areas. For example, a very extensive experiment to study the effect of low-level microwave radiation on the European honey bee has been conducted at the University of California at Davis. The results are now under analysis and a report is expected in the near future.

Should a second pilot beam be set up (e.g., by terrorists) to re-direct the beam, the beam will also defocus. This is a fall-safe fcature of the phasing system. In addition, the rectenna design includes sensors to detect any large changes to incident power density; this information would immediately be transmitted to the antenna to cease operations.27/ 
III.2 What are the atmospheric heating effects of decentralized solar energy systems compared to the SPS?

All of the waste heat generated by decentralized solar energy systems on Earth would be dissipated in the atmosphere near the Earth's surface. The amount of waste heat would depend upon the size and design features of individual systems. Undesirable effects produced by this waste heat would depend upon the characteristics of the environmental surroundings.

Most of the wast heat generated by SPS would be dissipated in space. Nevertheless, about 7 percent of the energy delivered to an SPS rectenna site would be lost as heat in the atmosphere near the Earth's surface. This heat loss is about the same as produced by contemporary suburban developments near large cities. Localized effects produced by SPS waste heat near rectenna sites, if they were to occur, would depend upon the characteristics of the environmental surroundings, as is the case for decentralized solar systems.

The waste heat which would be produced near SPS rectenna sites is not expected to affect regional weather patterns. Large terrestrial power generating systems capable of producing energy capacities equivalent to SPS would be expected to produce regional and global weather and climate effects which would be greater than any currently envisioned from SPS.

III.3 Will the SPS damage the ozone layer and create a "greenhouse" effect by heating up the atmosphere?

The bulk of the ozone is contained in the stratosphere between about 10 and $40 \mathrm{~km}$. This region has been under intensive investigation during the past ten years. Preliminary analyses $30 /$ indicate that effluents from SPS rocket launches would have a negligible effect on the ozone in this region. Above about $50 \mathrm{~km}$., where the ozone concentration is less than $1 \%$ its peak value in the stratosphere, preliminary analysis suggests that ambient water concentrations, especially abnve $70 \mathrm{~km}$, may be appreciably enhanced and may become involved in the complex chemical mechanisms which control ozone concentration at these altitudes. Even the direction of these effects is not predictable without a much closer examination. However, the above-mentioned preliminary calculations indicate that the globally averaged change in total ozone would be negligible (i.e., not detectable) and that, consequently, the change in intensity of ultraviolet radiation at the ground surface would also be negligible.

The reduced ability of the atmosphere to transmit long wavelength (infrared) radiation relative to shorter wavelength (visible and ultraviolet) radiation, commonly known as the "greenhouse" effect, most directly arises through the addition of light reflecting aerosols and infrared absorbing molecules $\left(\mathrm{CO}_{2}\right.$ and $\left.\mathrm{H}_{2} \mathrm{O}\right)$. As noted in the relevant documents $31 /, 32 /$, the relative abundance of these substances in the lower atmosphere is so large that SPS contributions are considered to be completely negligible. The water vapor budget in the stratosphere and above is poorly understood, so that at altitudes above 70 or $80 \mathrm{~km}$., SPS water vapor releases may enhance cloud cover. Although considerable uncertainty exists as to climatic effects arising from SPS-related perturbations in stratospheric and mesospheric composition, such perturbations are not expected to be highly significant. $33 /$

III.4 Why have only two years been allotted for atmospheric impact studies?

No fixer time has been "allotted" to any of the SPS assessment activities. Current atmospheric impact studies are part of the Concept Development and Evaluation Program, which for adminlstrative reasons is limited to three years. The planned studies in that time frame are to identify potential impacts on the atmosphere and to determine what is known and unknown about each impact. If, after considering all results of CDEP, it is decided to proceed further, the potentlal atmospheric impacts identified in CDEP will be addressed in greater depth and will continue until uncertainty regarding them has been reduced to a reasonable level.

III.5 Will communication systems already in place be disrupted by SPS operations?

Communications and other electromagnetic radiating systems must be designed and operated according to national and international rules and regulations for radio spectrum use. The SPS would have to satisfy these rules and regulations for compatible spectrum use, and where necessary, develop mitigating strategies to account for otherwise avoldable interference situations. Mitigating strategies can be (1) designed into new equipment, (2) followed in operating new equipment, or (3) applied to existing equipment with the users' agreement. 
Microwave energy from SPS could interfere with the operation of communication and other electronic systems now in use. In the absence of mitigating strategies, SPS interference effects would most likely occur in space and within about 100 kilometers of rectenna.sites.

Effects on satellites in space can be prevented by appropriate design of the SPS microwave transmission system, by coordinated operations with other satellites, and by including filters and shielding in future satellite designs.

Maximizing the distance between rectenna sites and taking advantage of the shielding provided by terrain features are two mitigating strategies which could be used on Earth. Interference effects which cannot be avoided by these techniques can be prevented by including conventional filters and shielding in new equipment designs and retrofitting existing equipment by mutual agreement. At this time, no unavoidable interference problems due to sPS are evident.

III.6 Would the current SPS reference system design create significant additional conflict over utilization of the geostationary orbit?

Obtaining orbital slots and radiofrequency allocation for many tens of SPS satellites - or other satellites - would require extensive international discussion and agreement. Use of the geostationary orbit by telecommunications and other geosynchronnus satellitco has been inciedsluy, and along with it, competition for orbital position. To date, the International Telecommunications Union, I.T.U., has assigned orhital slnte on a firot come, Clıs selved basis. However, this approach has created increasing conflict in the international community which considers the resource open to common use, and not subject to national appropirialiou. confliat focusea un lssues of exclusive use, technical debate over the number of orbital positions, and political disagreement on the Bogota Declaration, in which eight equatorial nations claim sovereignty over the geosynchronous orbit above their horders.33/ During the SrS operational timeframe it is anticipated that multiple use communications platforms will exist for which multiple communications antenna systems would be co-located. Such an arrangement may greatly reduce the slot allocation problem.

In addition, the level of microwave energy generated by and radiated from the SPS spacecraft has the potential to cause interference with communication or other satellites (including SPS's) located nearby. It is anticipated that multiple use communications platforms will come into being early in the next century which would tend to reduce the slot allocation problem. The SPS has focused attention on this issue which must be resolved whether or not SPS goes forward; an operational SPS, however, could be expected to intensify the debate.

III. 7 HOW will SPS's in GEO affect the aesthetics of the night sky?

SPS spacecraft would, if built according to the current Referenre System deeign, bo vioitle il cledr nlghts. Ihe visihle light from cach spaceirafl (sunlight diffusely reflected from the sular blanker array) would produce about $1 / 10 n$ n thr light of 2 fulli moon; the salelllies would be brighter than any object in the night sky except the moon.34/ Thcy would be brightest near midnight, comparable to Venus, and would become invisible near dawn or sunset since the large solar arrays would be seen "on edge" at these times. $35 /$

If 60 SPSs were positioned uniformly in GEO over the continental United States, the appearance would be that of a chain of bright planetlike object.s pxtending (2e viowcd from the U.3.) Iu a néarly straight line from east to west across much of the southern sky. They would be separated slightly less than are the stars in Orion's Bclt. These hright oblects would be in fixed position relative to the Earth, and stars and planets would thus appear to move from east to west past them. The relative brightness of the satellites, and their consistent spacing would contrast with the random configurations of stars that form the traditiunal consteliations. In addition, use of 7-power binoculars would clearly show them to be rectangular structures rather than points of light. L1ght from a large number of SPS satellites would brighten the night sky due to atmospheric scattering, and would be of some concern to astronomers.

At intervals of six months, the satellitcs would pass thruugh the Earth's shadow at approximately midnight for a number of days i.n succession: an occurrence something like a lunar eclipse. Satellites would dim and redden on encountering the edges of the shadow, darken, then reappear about 10 minutes later. The Earth's shadow could be seen to progress from east to west along the line of satellites. 
The current Reference System design calls for use of highly reflective material for the satellite transmitting antenna. Specular reflections from the large flat areas of the transmitting antenna would periodically direct bright beams of light across the night side of Earth. The reflection would be comparable to the full moon for two nights in spring and summer, lasting about 2 minutes.36/ The Environmental Assessment indicates that this amount of concentrated light from a small object may pose an eye damage risk to someone viewing the satellite through a telescope. Therefore, the present design for a highly polished antenna surface will be changed to eliminate the risk by permitting only diffused reflection of light. Means to further reduce the intensity of reflected light are also under consideration.

III.8 Have psychological factors affecting manned operations in the space environment been taken into account in studies of the health and safety of the space workers?

A preliminary study of the psychological factors affecting SPS space workers is in progress. Existing data that addresses this problem are available from the Skylab astronauts and Russian cosmonauts, submarine crews, oil platform workers, and the construction personnel on the Alaska pipeline. The question is of paramount interest, and will be pursued throughout the SPS program.

\section{ABOUT THE SOCIETAL EFFECTS}

IV.1 Why do we need centralized (baseload) power and a national energy grid? wouldn't a centralized system like the SPS reinforce the control that large institutions exert over people's lives? wouldn't reliance on the SPS inhibit a widely expressed desire to be more self-reliant through control of one's own energy supply?

The electric utility industry began as a highly decentralized activity with generation located close to the consumer and with virtually no interties between systems. Advancing technologies and economies of scale led to mergers and interconnections and have permitted utilities.to build larger plants and larger capacity transmission lines at decreasing unit costs. Interconnections have improved the reliability of utility systems and reduced generating reserve requirements. Presently, there are three major transmission networks - one each in the East, West and Texas - compused of utilities and pools intertied with each other, but the three networks are not connected. There is no national grid system, although its desirability continues to be debated:

The SPS is a centralized (baseload) power concept because it would transmit an essentially constant output through a grid network trom a site located at some distance from the point of end use. It is one of several baseload concepts proposed for use in the post-2000 era, and like the other systems would work best in a fairly substantial power pool. The sps does not require a national grid, however.

The debate over centralized vs. decentralized energy systems has arisen as one consequence of the tall-off of scale economies in the utility industry. Even assuming that utilization of decentralized energy systems increases over time, this does not rule out the need for a centralized" system to provide massive amounts of power for energy intensive processes (the production of aluminum and silicon used in decentralized technologies, for example) and to serve customers who do not find decentralization feasible. In this regard, the Argonne National Laboratory has recently published a report $37 /$ which suggests that it is the small commercial and industrial enterprise that would most likely suffer in a decentralized scenario.

Also, most decentralized technologies rely on a central system to provide back-up energy. If this adds to the existing peak demand, more centralized generating capacity would be needed, the utilities' load factor would be worse and electricity costs would be higher. On the other hand, if decentralized users could coordinate their demands to coincide with off-peak hours this would reduce total generating capacity required, improve the utflities' load factor and reduce the cost of electricity. It should thus be possible for distributed and centralized energy systems to develop a symbiotic relationship. Greater individual self-reliance through end-user ownership of decentralized systems, need not be threatened by the co-existence of centralized systems. 38 /

IV. 2 How could SPS development lead to decentralization of social institutions and decision-making structures? 
'The DOE assessment of the SPS has not formally dealt with this question, so that this answer must be speculative in nature. This question and the preceding one presume that decentralized energy systems lead to decentralization of social institutions and decision-making. Frankel $39 /$ and Stiefel $40 /$ suggest that this may not necessarily be the case. Both see the possibility that distributed solar energy technologies could be mass-produced, by huge factories and distributed to consumers by national (or international) merchandisers. Stiefel suggests that large corporations are ideally suited for mass-producing and distributing the many units needed for decentralized systems. This situation would engender some degree of individual ownership and control, but produce no fundamental change in the institutional or economic structure of society.

There are a number of ways by which SPS development could encourage decentralization:

- photovoltaics research could lead to more cost-effective ground-based systems for end-use applications

- mining, refining and manufacture of photovoltaic materials and other system components will have some, as yet undetermined, 1mpact on employment and population growth in rural areas; the result could be some shift in the balance of economic power hetween rural and urluall areas and geographic regions of the country

= SPS development could contribute to nragell otability lu unergy supp Hy and priccs, relieve long-term inflationary pressures and give individuals more confidence in making decisions about the future (ergo decreased sense of "being powerless")

It does not follow that because SPS development will require a high degree of central direction, decentralizing trends will be thwarted. Janowitz, in his book The Last Half-Century: Societal Change and Pollcics in America, discusses the War on Poverty and concludes that strong central planning is essential for genuine decentrallzation. Consider, for example, that the success of decentralized energy technologies in the marketplace will depend in large part on the central direction of the federal government.

The SPS would produce centrally generated electricity at sites remote from the end-user, but 1 t could still contribute directly to decentralization if its development were to create a dispersed system of ownership. Such a possibility is found in Vajk's taxpayer stock corporation model.11/ This financing scheme would diffusc ownership among the general population through the apportionment of shares in a so-called U.S. Powersat Service, based on the fraction of an individual's taxes devoted to the corporation. However, since Vajk says there is no historical basis for evaluating the scheme, it may be more realistic to assume some other financing scheme (which could employ this concept as one of its components) would be used. In this case, decentralization through SPS development is more likely to occur by indirect means.

IV. 3 What are the opportunity costs of developing the sps? Won't the diversiun of so much capital rob other promising energy technologies of development funds and leave the nation less flexible in responding to energy needs? What does the country do for its energy while it waits for the SPS to come on line?

In preliminary program phases, SPS incurs essentially no opportunity costs, since it does not reduce the development potential or funding of other promising technologies. sps funding in fiscal 1979 was $\$ 6.6$ milition; this accounted for less than $2 \%$ of the projected DoE budget for solar research and development studies, $42 /$ and is less than $0.1 \%$ of the total. energy ragearch and development. buidget.

A decision to fully deploy a Satellite Power System would be accompanied by a massive financing effort and a decision to obtain the resultant power in this manner rather than in snme othor way. Opportuntty costs wnild therefore lip lusurrad. Lt would uut, however, necessarily restrict research funds or inhibit the early development of other promising energy technologies. Demand for electricity will grow significantly by 2000, and neither the SPS nor any other single energy technology will be able to supply all electric demand. It is likely that many systems will be developed to provide maximum flexibility in responding to cnergy needs.

The resulting mix, and hence the exact opportunily cuses, will be decided in a rather dynamic fashion over time by economic and political factors that can scarcely bc foreseen now. 
The SPS would come on line gradually (10 GW per year are currently envisaged) and would generally meet increasing demands or replace obsolete generating capacity.

IV.4 Who will be the economic beneficiaries of the SPS? The impression is that only aerospace companies and their workers will benefit.

The aerospace industry may be the most visible group to benefit from the SPS. Other sectors, , although less visible, would significantly benef1t; the SPS would not be developed by the aerospace Industry alone.

All industries involved in the SPS, and their employees would benefit from the SPS. Affected industries include chemicals and allied products, mining, primary metals, semi-conductors, space vehicle manufacture, ground operations and supporting services. Of the large amount of solid material required for an SPS system, over 90 percent is in the ground based rectenna and approximately 6 percent is in the launch site complexes. Only 2.4 percent is in the SPS satellites, and space transportation system. Of the labor required to build, operate and maintain and repair the SPS system, more than 99 percent can be classified as belonging to conventional occupations and industrles listed above, and less than 1 percent work in the space environment.43/,44/ Other industries to directly benefit would include those who own land to be used for rectenna and launch sites, finance and manage an SPS, and distribute SPS power (utilities).

Communities and individuals would benefit indirectly, through an economic multiplier effect that accompanies any economic development. Each individual directly benefitting would, in turn, distribute benefits to others directly. Significantly, all power users would benefit if the SPS can provide cheap, reliable electric power. In particular, a recent study reported that the SPS, a central solar technology, might more reliably serve the energy needs of the aged than would decentralized solar technologies.45/ Perhaps the least visible sector would be the future beneficiaries of space utilization that SPS rapabilities would make possible.

IV.5 Who will provide insurance for the SPS? For damage from occupational exposure, wandering beams and crashes à la sky Lab?

A market for space insurance has been developing in the U.S. and England since launch of the first commercial satellites, in the ' $60^{\prime} \mathrm{s} .46 /$ As with other industries, the space industry has sought to protect itsclf from loss of investment; a space insurance market has developed that includes coverage for loss against $R \& D$, manufacture, launch and operation of satellite systems.

However, it appears that a satellite system with the scope of the SPS would challenge the existing space insurance industry. The SPS Project Division has therefore contracted a major space insurance broker to determine how the industry would respond to the SPS. The study is to (1) review the history of space insurance coverage; (2) identify SPS insurance risks by component (satellite, microwave power transmission system, etc.) and program phase (construction, operation, etc.); (3) identify the insurance industry response to the SPS; and (4) determine risks the insurance industry could indemnify and estimate the cost of coverage.

The nation that develops an SPS would be liable, legally, for any damage that might occur, and would require private developers to insure the system. The 1972 multilateral convention on International Liabillcy for Damage Cauoed by Spare nhjects holds the launching state "liable to pay compensation for damage caused by Its space object on the surface of the Earth or to aircraft in flight." Were an international SPS developed, the states involved would be held jointly liable.

Note: The pilot uplink beam controlling the microwave transmission would preclude the possibility of wandering beams. Objects placed in geostationary orbit (such as SPS) where there is no atmospheric drag, can rather easily be maintained there indefinitely. Skylab could have been maintained in orbit as well; for a variety of reasons, none involving technological capability, it was not.

IV.6 Why is it necessary to study the military implications of the SPS? Is the SPS's primary purpose a military one? How vulnerable is the system to sabotage and therefore to disruption in the supply of energy?

The SPS is an energy system. It may have military applications; several have already been suggested.47/ However, to be a viable energy system the SPS should be kept out of the military realm. 
Preliminary assessments of the military implications of the SPS were made by Bain $48 /$ and Ozeroff $49 /$. The objectives of the investigations were (1) to identify the potential military uses for the SPS and how these would affect international relations, and (2) to identify the relative vulnerability of the SPS to overt military action, terrorist attacks and sabotage. The SPS Project Division accepted the findings of these preliminary assessments, and the general consensus among other investigators who touched on the subject, that: (1) a completely internationalized SPS would have the most beneficial effect on international relations (indeed, on domestic acceptance of the system, as well) and, (2) any military application would be likely to destabilize international relations.

Internationalization of the SPS could nearly eliminate the vulnerability of the system to overt military action, especially if participation in its development were broadly-based and substantial. The system might still be vulnerable to terrorist attack or sabotage although, as Bain and Ozeroff found, 1 t is unlikely that the space segment would be threatened by such actions. The rectenna facility would be no more vulnerable to these actions than other large industrial complexes or power plants, and might, in fact, be less vulnerable since no terrestrial fuel supply lines are required. $\underline{50 /}$

A follow-on study has been initiatcd to impruve upon the preliminary assessment. Its purpose is to make an in-depth analysis of the ways to counteract real and perceived potential military threats and vulnerabilities of the SPS and its components. This study will be completed in the early Fall 1980.

IV.7 Will development of the SPS seriously deplete any of the firth's rcoources?

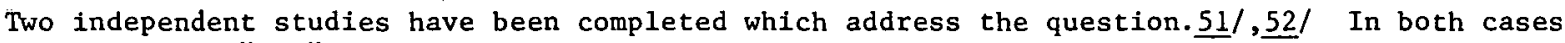
the answer is "no." Both studies screened the twenty two hasic materiale required for SPS production and both found some problems in the supply or production of certain materials.

The more serious problems are those associated with the solar cell materials (gallium, gallium arsenide, sapphire, and solar grade silicon), and the graphite fiber required for the satellite structure and space construction facilities. In addition to these mercury, tungsten and silver were found by both investigators to be potential problems as were kapton, borosilicate glass and liquid hydrogen.

Most of these are problems in terms of currently identifled reserves, production capabilities, import requirements and the like and could be ameliorated. For example, gallium, which both investigators class as perhaps the most serious problem is judged "not to be a limiting factor over the long term" by the Aluminum Company of America.53/

IV. 8 Have other countries been approached to participate in sPS studies? If so, which ones?

No formal arrangements have been made between the U.S, and foreign countrias or Interuational agenc1es to partlelpate in studies sponsored by the SPS Project Division. Informal contacts have been made with the European Space Agency and several individual countries in Europe and throughout the world. Interest in the SPS concept is widespread and growing among members of the international scientific communtty. Individuals from Czechoslovakia, England, France, Germany, Japan and Russia have published the results of recent, independent work on various aspects of

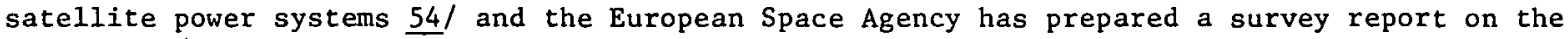
subject. $\underline{5}$ /

Obviously, if the SPS is to be intcrnationalized, formal arrangements with other nations and international agencies will have to be made. As part of the current assessment program, a study is being prepared to develop options for involving the intornational cuimumlly in any fulust SPS program activities.

IV.y Who would provide SPS development funds and who would control and maintain the SPS once it was developed?

This is as yel an open question. Several financing and management options have been identified which could support development of the SPS. $56 /, 57 /$ The form of the organization has yet to be worked out, although there is 1.ikely to bc a wide range of participants, both national and international, public and private. The general consensus among the principal investigaturs involved in the prellminary phases of the SPS is that international cooperation in R\&D and 
some commercialization would be highly desirable. The International Telecommunciations Satellite Organization (INTELSAT) is an example of an existing international framework that an SPS organization might be modeled after.

Kierulff showed that it would be extremely difficult for the private marketplace to completely finance an SPS. Thus, the federal government would have to provide a major portion of the funding and/or guarantee investment vehicles in the late 1990's and early $2000^{\prime} s$ as was done in the early phases of nuclear power and communications satellite development.

Control of the system would rest to a large extent with the investors and whatever organization they established after approval of all concerned parties. The federal government would also exercise control through regulation. State and local governments would exercise a degree of regulatory control over siting and operation of the rectenna facilities. However, as Kotin noted $58 \%$, some of the key regulatory issues which remain to be resolved involve jurisdictional conflicts between the various levels of government and conflicting siting and land use policies.

At the international level, certain control mechanisms already exist for satellites operating in geostationary orbit. The International Telecommunications Union assigns portions of the radio frequency spectrum to the various users and regulates signal interference characteristics of satellite systems. The organization which develops and maintains the SPS will have to abide by other existing international space treaties and will, itself, almost certainly be the cause of several new international treaties and regulatory bodies.

IV. 10 Is a disruption of SPS power likely? What happens to an area which derives some or all of its energy from an SPS should such an event occur?

The SPS is envisioned as a large base load power system connected to a power grid. It will be handled like any other power source on the grid. As a contingency against loss of power, utilities are required to maintain a portion of their total generating capacity on line as "spinning reserve". In the event that a unit(s) experiences sudden failure (loss of power) these spinning reserve units instantaneously cut in to provide power to the grid. Transmission line interties to other utilities and pools are also traditionally used to provide immediate power flow into the grid.

A preliminary investigation of the SPS by some electrical engineering experts has found that the SPS may be more reliable than existing power generating systems (nuclear, coal, oil, gas turbine, etc.). $59 /$ SPS would be generating power a higher portion of the time and would be less prone to non-scheduled power outage. However, interruption of SPS power will occur at known periods of time due to shadowing of the satellite by the Earth. Fortunately, these outages occur at local midnight when power requirements are low. A 5 GW SPS unit would be connected to a pool 60/ 30-35 GW or larger, and the scheduled SPS outage would be accommodated by reserve within" the pool, or through interties.

No area would derive all of its electrical power from the SPS. A 5 GW SPS unit would not be used to supply more than about $20 \%$ of the total electric generation capacity for any single utility or pool. Non-scheduled disruption of SPS power would be highly unlikely, but not impossible. Were partial or complete outage of an SPS unit to occur, power levels would be maintained by ne or a rombination of the mechanisms outlined above,

IV.11 Is there any public awareness of the SPS as a major candidate for long term energy generation?

There is some public awareness of the SPS as a long-range energy option, but no systematic attempt has been made by the Project Division to assess its extent. It can be inferred that knowledge of the SPS is growing. For example, the Project Division distributes approximately 3,000 copies of each report it publishes. These reports are distributed to a wide national and international audience that includes universities, government agencies, libraries, public and private interest groups, corporations, and individuals interested in SPS activities and work.

Certain specific groups in this country and abroad are quite knowledgeable about the SPS. At least two national engineering associations, representing 200,000 members in electrical, electronics, aerospace, and systems disciplines, have run articles on the SPS in their journals.61/ The SPS has been the subject of several presentations at meetings of the Royal Aeronautical Society and the International Astronautical Federation in the last few years. 
The question was generated in the Public Outreach Experiment sponsored by the Project Division. In this experiment, summaries of twenty SPS reports were mailed to 9,000 recipients associated with the three' public interest groups: Citizens Energy Project, Forum for the Advancement of Students in Science and Technology, and the L-5 Society. Over 1,500 responses have been received from mailings.

The national news media have also featured reports on SPS for the general public. The MacNeil/ Lehrer Report had a nationally televised discussion of the pros and cons of the SPS on June 14, 1978. Several articles have appeared in the Los Angeles Times and the New York Times.

Finally, the Project Division responds affirmatively to every request for information and operates under a policy of openness and accessibility.

IV.12 What constituencies are being studied for their probable response to the SPS?

There are no constituencies being studied, per se. Three groups - the Citizens Energy Project, the L-5 Society and the Forum for the Advancement of Students in Science and Technology - are cooperating with Planning Research Corporation in eliciting comments from members on results of the SPS program and in establishing a dialogue between the Project Division and these individuals. This dialogue serves several useful purposes. The Project Division can see if there are any concerns which are not being adequately addressed in the current assessment program. Furthermore, the questions which members of the three urganizations pose enable the Project Division and the field staff to become more aware of the specific concerns people have about the SPS.

The Project Division has also funded a study by Rice University to place the SPS debate within a broad social and cultural milieu. The objective of the project is to identify and relate the socfocultural factors which shape the public acceptability of advanced technologies. The study will attempt to do this by reviewing the public debate over large-scale commitments of public funds for the development of the nuclear industry and other highly sophisticated technologies. opinion poll data covering energy-related issues will also be analyzed.

The findings of these projects will be used by the Project Division to develop a continuing outreach program and to develop a process for long-term public involvement should the SPS program be continucd.

V. ABOU'I' 'I'HE' DOE PROGRAM

V.1 Why is DOE even involved in the evaluation and development of the SPS? why isn't the private sector doing this on its own?

The concept of generating large amounts of electric power using satel1ites in space and transmitting it to Earth originated in the private sector. A.D. Little's Peter Glaser first suggested the idea in 1968. The private sector has continued ton follow development of the concept with interest. Public sector involvement in SPS investigation started relatively recently. The SPS is a long-term, large-scale venture, and has the promise to make a major impact on this nation's energy supply and economic situation if proven safe, and feasible technically and economically. This provides the basis for DOE interest. The DOE has supported a program to evaluate the SPS concept since 1976.

The major U.S. aerospace companies have taken an active interest in the SPS concept since it was first proposed, and have continued to support independent work on SPS design studies. The Electric Power Research Institute, a private research organization funded by member utilities, is currently funding a study of SPS-utility integration issues. However, long-term investment in high-risk ventures demands a much more significant commitment by the private sector than is generally possible. Note, for example, federal government involvement in encouraging the commercialization of distributed energy systems. Ball's discussion of the synfuels challenge to industrial decision-making is very pertinent $\underline{62}$ /:

"For conventional major capital investments to be attractive, they must be viable for a quarter-century or more....familiar tools for evaluating investment decisions over long time spans hecome litt.le more than arademir pxerrises in a totally undefined industry..." 
Space development ventures traditionally have been economically risky, and supported by federal financing. Once the technical and economic viability of a system has been demonstrated, the private sector has stepped in to develop the market. This was true for communications satellites, and will probably be true for the SPS. Therefore. it is likely that the major source of funds to support continued SPS evaluation will be the public sector, assuming the necessary policy. decisions are made to proceed with the program.

V.2 Many respondents appear to believe that the objective of the CDEP effort is to plan for the commercialization of the SPS. The actual objectives of the DOE study are not clearly understood. To what areas of investigation are the program funds being allocated? How much of the total is going to environmental studies?

The SPS Project Division's objective in undertaking the Concept Development and Evaluation Program (CDEP) is "to develop, by the end of 1980, an initial understanding of the technical feasibility, economic practicality and the social and environmental acceptability of the SPS concept".63/ The intent is to provide the government and the American people with the information they need before deciding to embark or not to embark, on the next stage of the SPS investigation. A decision to proceed would not result in commercial development of the SPS in 1980 , but would result in implementation of a follow-on program, Ground Based Exploratory Development (GBED). This 7-9 year program would further reduce uncertainty about the SPS system design, its technical characteristics, and potential environmental and societal effects. The GBED would be followed by technical verification of the SPS if that were judged to be advisable.

CDEP Element
Systems Definition
Environmental Assessment
Societal Assessment
Comparative Assessment
Emerging Technologies
Analysis/Planning

Total

$$
\begin{aligned}
& \text { Funding } \\
& \$ 6,600,000 \\
& 6,500,000 \\
& 1,700,000 \\
& 1,700,000 \\
& 1,400,000 \\
& 1,700,000 \\
& \$ 19,600,000
\end{aligned}
$$

This table shows that about one third of the approximately $\$ 20$ million budgeted for the threeyear CDEP program is allocated to defining the reference system. The remaining two-thirds is dedicated toward evaluation of the concept. The evaluation assumes implementation of the SPS in accordance with the reference system and asks: what is the environmental impact? How is society likely to be affected? How might it compare with alternate sources of energy? What alternative approaches might be used to obtain terrestrial power from satellites?

The Environmental Assessment will identify and assess environmental issues associated with SPS reference system development and operation. These have been grouped into five general categories. Microwave health and safety effects account for aoout $30 \%$ of the budget; non-microwave health and safety about 10\%; atmospheric effects, ionospheric effects and electromagnetic compatibility (radio-frequency communication effects) each account for about $20 \%$ of the budget.

V.3 Just how much information on the SPS is available to the general public? Has such information appeared in the media? What agencies of the federal government have information that the public could obtaln?

The Project Division has encouraged inquiries about the SPS assessment it is conducting since the beginning of the program. All finished reports are available to the public through the National Technical Information Service (NTIS):

\author{
U.S. Department of Commerce \\ 5285 Port Royal Road \\ Springfield, VA 22161
}

The Project Division also maintains an SPS Library which is operated by the Argonne National Laboratory for the DOE. The Library has on file a limited number of copies of all current reports on the SPS and related topics. The Library periodically updates its bibliography of papers, reports, books and magazine articles on the SPS. Bibliographic inquiries should be directed in writing to: 
Argonne National Laboratory

Satellite Power System Library, Rm. 185

400 No. Capitol Street, N.W.

Washington, D.C. 20001

The public can obtain copies of House and Senate hearings on the SPS. The hearings have included testimony from supporters and opponents of the SPS. In the House, the Science and Technology Subcomittee on Space Science and Applications has held hearings on the SPS on February 15, March 28-30 and May 2, 1979. The Senate Energy and Natural Resources Subcommittee on Energy Research and Development held a hearing on August 14, 1978. These committees may be contacted at the following addresses:

\author{
United States Senate Committee \\ on Energy and Natural Resources \\ Washington, D.C. 20510 \\ U.S. House of Representatives \\ Committee on Science and Technology \\ Washington, D.C. 20515
}

Occasional articles dealing with the SPS have appeared in newpapers and magazines. For example, the New York Times devoted two pages to a review of the SPS concept in February 1979 . The SPS concept has been referred to in articles dealing with space industrialization and space colonization in magazines having a national circulation, such as Fortune, Nation's Business, and Mother Jones. Mention of the SPS appeared in the national print media when President Carter enunclated his administration's space policy objectives and has continued in the coverage of the ensuing Congressional debates over this policy.

V.4 How realistic does DOE consider the SPS to be?

There has been a logical progression of growing interest in the SPS within the public and private sectors since the concept was first proposed by Peter Glaser in 1968. NASA considered the concept realistic enough to fund some SPS studies out of its "advanced studies" budget through FY76. Private corporations supported some small studies during this period, too. Congress also began to take notice of the SPS and in 1973 the first Congressional hearings of note took place. In early 1976, the Department of Energy (then, the Energy Research and Development Administration) established a Task Group on Satellite Power Stations to review past work and suggest future options.

After fiscal year 1976, the Office of Management and Budget transferred responsibility for SPS studies to ERDA (nOw DOE) since the SPS is basically an energy option. The Task Group found that the SPS showed sufficient promise to recommend a more detailed assessment in accordance with a defined set of activities. This recommendation formed the basis for the three-year Concept Development and Evaluation Program presently nearing completion. This program will provide the information from which a pólicy decision can be made to proceed further or not, and if so, at what pace.

The DOE, therefore, considers the SPS to be realistic enough to have undertaken a rather extensive concept development and evaluation program designed to determine what is known and unknown about the system and its potentlal impacts. The policy decisions to be made later this year will indicate how realistic the DOE considers SPS to be at that time.

V.5 On what does success of the SPS depend? How much will it cost to decide whether or not to go ahead wirh the Sips?

The success of the SPS will ultimately depend on its proven ability to provide baseload electric power safely and economically. Such an achievement could be met only with the successful completion of a series of programs designed to evaluate, and if recommended, to fully address technical, environmental and societal issues.

The three-year Concept Development and Evaluation Program, (CDEP), nearing completton, has been undertaken as the first step.64/ The CDEP objective is to develop an initial understanding of SPS system requirements, technology goals and their feasibility; identify the system's environmental and societal affects and their acceptability; and evaluate the SPS compared with alternative energy systems. 
The CDEP has been designed to identify any major SPS problems and their magnitude, and determine whether these would foreclose the SPS option, or could be resolved through additional study, system design changes, or mitigation procedures. Integrated results of the CDEP study will provide information from which an informed decision to either terminate the program, or continue it in accordance with a defined option, can be made. Such a decision will have cost approximately $\$ 20$ million.

If no "program stoppers" are identified in the CDEP (none have been identified to date) a Ground Based Exploratory Development Program (GBED) could succeed it if the appropriate policy decision is made. The seven to nine year GBED program would consist of ground based experiments and exploratory research investigating the reference system and alternative systems and subsystems.

The GBED objective is to reduce uncertainty about SPS feasibility and viability to the point where an informed decision could be made regarding initiation of an even more intensive research and development program leading to prototype components, on-orbit testing, and verification of the required technology. The costs of the GBED program, which would start in 1981, have not yet been estimated but will exceed CDEP costs by at least an order of magnitude.

V. 6 Can energy self-sufficiency be arrived at through the SPS?

Clearly, no single energy technology will solve our energy problem. However, the SPS, working in concert with a mix of other systems, could make us less reliant on non-renewable energy sources and help the U.S. become more energy self-sufficient.

In 1976, the U.S. consumed 74 quadrillion Btu 65/ ( 1 quadrillion = 1000 trillion), or the Btu equivalent value in petroleum (including oil and gasoline), coal, electricity, and other energy forms. Forty-seven percent of all energy consumed was supplied by petroleum; $27 \%$ by natural gas; about $19 \%$ by coal; hydropower and nuclear energy supplied about $4 \%$ and $3 \%$ respectively. Although energy consumption is distributed more or less evenly by the four main end use energy sectors, energy supplies vary widely by end use sector.

\begin{tabular}{ll} 
End Use & Total \\
Energy & Energy \\
Sector & Consumption (\%) \\
\hline
\end{tabular}

Commercial 20

and household

natural gas petroleum electricity

Industry

Transportation

Electricity
26

29 natural gas $\quad 41 \%$

coal

$28 \%$

petroleum $18 \%$

electricity $24 \%$

petroleum $97 \%$

(primarily gasoline)

coal 45\%

petroleum $16 \%$

nacural yas $15 \%$

hydropower $14 \%$

nuclear

As the chart indicates, we need to provide energy in a form appropriate to its end use. Conservation in all sectors can reduce energy consumption by increasing energy use efficiency. Passive and active solar technologies may efficiently provide energy for space and hot water heating (such heating accounts for $67 \%$ of total residential sector energy use). However, it is evident that these technologies will not provide energy appropriate to all end uses.

The SPS promises to supply large blocks of baseload electric power that can contribute to all electricity consuming sectors. In $1976,60 \%$ of generated electricity was consumed by the household and commercial sector; $40 \%$ was consumed by the industrial sector. A recent DOE report $67 /$ projects 1990 energy consumption at 94 to 110 quadrilition Btu, assuming $1.6 \%$ and $2.8 \%$ annual growth rates for energy consumption. In either case, electricity would be $38 \%$ of total energy consunption (versus $29 \%$ in 1976), and would make up a significantly higher portion of total 
energy consumption in each sector than occurs at present. The SPS could significantly contribute to U.S., and global energy self-sufficiency, but could not alone achieve it.

V.7 Does the DOE believe that SPS development will reinvigorate the U.S. internally and give it a renewed position of leadership abroad?

The DOE's current interest is in determining the practicality of the SPS concept as an energy source. It is premature, and probably wrong, to assume that the development of the SPS alone would provide the lasting and profound impact on society that the question suggests. This is especially so when one considers the array of technical, environmental and societal problems which must be solved prior to assuming such a vast undertaking. However, the SPS, if it is to be built at all, may well be just one part of a reinvigorated program of space application and research that would enhance U.S. prestige on a worldwide basis.

Developments associated with transportation to space, space manufacturing and assembly and construction of large space structures are areas where technological leadership would be developed. The broad spectrum of technological challenges to implementing the SPS program might well keep the U.S. on the cutting edge of technology advancement for many years. SPS development would also provide an opportunity for significant international, ronperation in exploring and exploiting the benefits of outer space and its resources. More importantly, perhaps, SPS development would provide badly needed energy to many countries of the globe with consequences that must on balance be beneficial, but largely unpredictable in terms of impact on the U.S. 
1/ Memorandum EW4-79-126 from Johnson Space Center (EA4, Associate Director for Program Development) to NASA Headquarters (RES-1/Manager, Space Utilization Systems), Re: SPS System Orbital Decay, 2 August 1979.

2/ "Key Crude Oil and Product Pipelines Are Vulnerable to Disruption", EMD-79-63, U.S. General Accounting Office, August 27, 1979.

3/ Space and Planetary Environment Criteria Guidelines for Use in Space Vehicle Development, 1977 Revision, NASA Technical Memorandum 78119, November 1977.

4/ SPS Reference System Report, DOE/ER-0023, October 1978, pp. A42-A44.

5/ General Electric Space Division (GE) Solar Power Satellite System Definition Study Part 4 Phase 1 Final Report, GE 1979, reported in: "Prototype Environmental Assessment of the Impacts of Siting and Construction of a Satellite Power System (SPS) Ground Receiving Station (GRS): Project Description," ERG, (November 1979).

6/ Briefing given on Satellite and Rectenna Construction and Maintenance, "Some JSC SPS Activities," NASA JSC, November 28, 1979.

7/ SPS Concept Development and Evaluation Program Reference System Report U.S. DOE/ER-0023, October 1978.

8/ Life Support, NASA Office of Aeronautics and Space Technology, Summer Workshop, Volume XI, August 1975 .

9/ Manpower requirements supplied by H. Donald Calahan, NASA/SPS Program Manager, NASA Headquarters, Washington, D.C., December 6,1979.

$10 /$ Lewis, Bill, "Assessment of the Effects of Zero Gravity Environment on the Health and Safety of Space Workers," briefing presented at NASA Johnson Space Center, November 1979.

11/ Adapted from Table 3.11 of "Preliminary Comparative Assessment of the Satellite Power System and Alternative Technologies" by T. Wolsko, et al, Argonne National Laboratory (in press).

12/ "Costing the Satellite Power System" by Dr. George A. Hazelrigg, Jr., American Astronautical Society, paper No. AAS 78-166, November 1978.

13,14/ Testimony and prepared statements of Robert Frosch, NASA Administrator, and F.A. Koomanoff, Director of the SPS Project Division, before the House Science and Technology Subcommittee on Space Science and Applications, March 29, 1979.

15/ "Preliminary Comparative Assessment of the Satellite Power System, and Alternative Technologies," by $T$. Wolsko, et al, Argonne National Laboratory (in press).

16/ "Preliminary Comparative Methodology for SPS and Alternative Technologies," Argonne National Laboratory, May 1979.

17/ Initial Technical, Environmental and Economic Evaluation of Space Solar Power Concepts, JSC 11443 Volume I, National Aeronautics and Space Administration, July 15, 1976.

18/ Satellite Power System, NASA TM X-73344, National Aeronautics and Space Administration, November 1976.

19 / C. Bloomquist, A Survey of Satellite Power Stations, PRC R-1844. PRC Systems Sciences Co., Los Angeles, California, September 1976.

20/ Final Report of the ERDA Task Group on Satellite Power Stations, ERDA-76/148, Energy Researç and Development Administration, Nuvember 1976.

21/ Livingston, Floyd R., et al, Satellite Power System (SPS) Preliminary Resource Assessment, 900-805, Rev. A, Jet Propulsion Laboratory, California Institute of Technology, Pasadena, California. August 7,1978 . 
22 / Kotin, A., SPS Preliminary Societal Assessment: Resources Requirements (Critical Materials, Energy and Land), DOE HCP/R-4024-02, October 1978, PP 66-70.

$23 /$ R. Herendeen, T. Kary, J. Rebitzer, Energy Analysis of the Solar Power Satellite, ERG Doc. No. 265, Energy Research Group, University of Illinois at Urbana, Champaign, Urbana, IL, November 1978.

$24 /$ Herendeen, R.A., T. Kary and J. Rebitzer, "Energy Analysis of the Solar Power Satellite," Science, 3 August 1979, Volume 105, Number 4405, pp 451-454.

25/ The final report is due in May 1980; preliminary results were given in: Blackburn, James B. Jr., and Bill A. Bavinger, SPS Preliminary Societal Assessment: Mapping of Exclusion Areas for Rectenna Sites, DOE HCP/R-4024-10, October 1978.

$26 /$ Energy Supply and Demand in the Mid-Term: 1985, 1990 and 1995, DOE/EIA-0102/52 Order No. 476, April 1979.

27/ Technical information on the microwave power transmission system is taken from the SPS Reference System Report, \#DOE/ER-0023, October 1978, pp. 30, 33, 45.

28/ Briefing by John Allis of EPA on SPS Microwave Bioeffects Studies, presented at a June 1979 SPS Review in Washington, D.C.

29 / SPS Preliminary Environmental Assessment, DOE/ER-0021/2, October 1978, pp. 86, 106.

$30 /$ SPS Preliminary Environmental Assessment, DOE/ER-0021/2, October 1978, PP. 86-91.

31/ SPS Preliminary Environmental Assessment, DOE/ER-0021/2, October 1978, p. 32.

32/ SPS Preliminary Environmental Assessment, DOE/ER-0021/2. October 1978 .

33/ Christo1, Car1 Q. SPS Preliminary Societal Assessment: International $\Lambda$ greements, DOE HCP/R-4024-08 October 1978 .

34/ SPS Preliminary Environmental Assessment, DOE/ER-0021/2, October 1978.

35/ Livingston, L.E, Briefing on Visibility of SPS, presented at NASA JSC, June 6, 1979.

36/ Livingston, L.E., "Visibility of Solar Power Sacellites from the Earth", NASA Johnson Space Center, JSC-14715 report, Heb., 1979.

37/ Asbury, J.A. and S.B. Webb, "Centralizing or Decentralizing? The Impact of Decentralized Electric Generation," ANL/SPG-16, Argonne National Laboratory, March 1979.

38/ "Tentralized vs. Decentralized Energy Systems: Diverging or Parallel Roads?". prepared fü the Subcommittee on Energy and Power, House commictee on Iuteistate and Foreign Commerce, by the rongressional Research Service, May 1979, p. 18.

39/ Franke1, "Some Thoughts on Solar Energy and the Decentralist Vision", office of Policy Evaluation, U.S. Department of Energy, 1979.

40/ Technology Review, October 1979, pp. 56-66.

41/ Vajk, et al, SPS Preliuinary Joc1ctal Abstssulnt: Financial/Managoment Shenarios. DOE 非CP/R-4024-03, October 1978.

$42 /$ Report of the Comptroller General of the United States, "l'he Magnltude uI the Fedcral Solar Energy Program and the tittects of DLffetent Levelo of Funding." GAn:FMD-78-27. February 1978.

43/ "Satellite Power System (SPS) Environmental Impacts-Preliminary Assessment, "NASA/JPL, April 1, 1978.

44/ "Satcllite Power System (SPS) Preliminary Resources Assessment," Jet Propulsion Laboratory-Calif. Institute of Technology, JPL, August 7, 1978.

45/Cambel, Ali, G.A. Heffernan. Implications of an Aging Society on Satellite Power System. The Office of Energy Programs, School of Engineering and Applied Sciences, The George Washington University, December 1979. 
46/Barrett, James and Smith, Delbert, "The Role of Insurance in Expanding International Space Opportunity," paper presented at the Thirtieth International Astronautical Federation, Munich, Germany, September 1979.

47/See, for example, Berger, Howard, et. al, "Effects of Technological Advances on International Stability: High Energy Lasers in Space,"' Science Applications, Inc., August 1977.

48/Bain, Claud N., SPS Preliminary Societal Assessment: Military Implications, DOE HCP/R-4024-11, October 1978 .

49/Ozeroff, Michael J., SPS Preliminary Societal Assessment: Military Implications, DOE HCP/R-4024-01, October 1978.

50/"Key Crude Oil and Product Pipelines are Vulnerable to Disruption," EMD-79-63, U.S. General Accounting Office, August 27, 1979.

51/Kotin, Alan, SPS Preliminary Societal Assessment: Resource Requirements, DOE HCP/R-4024-02, October 1978.

52/Teeter, R.R. and W.M. Jamieson, "Preliminary Materials Assessment for the Satellite Power System," Battelle Columbus Laboratories, September 1979.

53/"Survey of Availability and Economical Extractability of Gallium from Earth Resources" Aluminum Company of America, October 1976.

54/See for example the "Abstract of Papers," XXXth International Astronautical Congress of the International Astronautical Federation (I.A.F.), September 16-22, 1979, Munich, Federal Republic of Germany.

55/Ruth, J. and W. Westphal, "Study on European Aspects of Solar Power Satellites," European Space Agency, June 1979.

56/Kierulff, Herbert E., SPS Preliminary Societal Assessment: Financial/Management Scenarios, DOE HCP/ R-4024-13, October 1978 .

57/Vajk, J. Peter, SPS Preliminary Societal Assessment: Financial/Management Scenarios, DOE'HCP/R-402403 , October 1978 .

58/Kotin, A. SPS Societal Assessment: State and Local Regulations as Applied to Microwave Rectenna Facilities, DOE HCP/R-4024-05, October 1978, pp 44-46.

59/General Electric Presentation at NASA/Johnson Space Center, August 16, 1979.

60/Group of closely interactive utilities, usually geographically contiguous.

61/The July and September 1979 issues of the IEEE Spectrum and the AIAA Position Paper of November $20,1978$.

62/ Ball, "New Challenges th Management in the Synfuels Revolution", Technology Review, August/September 1979 , pp. 34 and 35 .

63/Taken from a policy statement on the SPS issued by the Secretary of Energy.

64/SPS Concept Development and Evaluation Program Plan, July 1977-August 1980, DOE/ET-0034, February 1978.

65/The British thermal unit, Btu, is used as a measure of energy. One Btu = the quantity of heat required to raise the temperature of 1 pound of water 1 degree Fahrenheit at standard atmospheric conditions.

66/Energy Information Handbook, Congressional Research Service; prepared for the House Interstate and Foreign Commerce Subcommittee on Energy and Power, July 1977.

67/Energy Supply and Demand in the Mid-Term: 1985, 1990, and 1995, DOE/EIA-0102 Order No. 476, Apri1 1979. 
United States

Department of Energy

Washington, D.C. 20585
THIRD - CLASS MAIL POSTAGE \& FEES PAID

U.S. DEPT. OF ENERGY

PERMIT NO. G 20

THIRD CLASS MmIL

Official Business

Penalty for Private Use, $\mathbf{\$ 3 0 0}$ 